\title{
Effects of iron and light availability on phytoplankton photosynthetic properties in the Ross Sea
}

\author{
Anne-Carlijn Alderkamp ${ }^{1,2}{ }^{,}$Gert L. van Dijken ${ }^{1}$, Kate E. Lowry ${ }^{1}$, Kate M. Lewis ${ }^{1}$, \\ Hannah L. Joy-Warren ${ }^{1}$, Willem van de Poll ${ }^{3}$, Patrick Laan ${ }^{4}$, Loes Gerringa ${ }^{4}$, \\ Tom O. Delmont ${ }^{5,7}$, Bethany D. Jenkins ${ }^{6}$, Kevin R. Arrigo ${ }^{1, *}$ \\ ${ }^{1}$ Department of Earth System Science, Stanford University, Stanford, CA 94305, USA \\ ${ }^{2}$ Biology Department, Foothill College, Los Altos Hills, CA 94022, USA \\ ${ }^{3}$ Department of Ocean Ecosystems, University of Groningen, PO Box 11103, 9700 CC, Groningen, The Netherlands \\ ${ }^{4}$ Royal Netherlands Institute for Sea Research, OCS, University of Utrecht, PO Box 59, 1790 AB, Den Burg, The Netherlands \\ ${ }^{5}$ Department of Medicine, University of Chicago, Chicago, IL 60637, USA \\ ${ }^{6}$ Department of Cell and Molecular Biology and Graduate School of Oceanography, University of Rhode Island, Kingston, \\ RI 02881, USA \\ ${ }^{7}$ Present address: Génomique Métabolique, Genoscope, Institut François Jacob, CEA, CNRS, 91000 Evry, France
}

\begin{abstract}
Waters of the Southern Ocean are characterized by high macronutrient concentrations but limited availability of trace metals and light, often making it difficult for phytoplankton to achieve maximum growth rates. One strategy employed by Southern Ocean phytoplankton in culture to cope with low light and low dissolved iron (DFe) is to enhance light absorption by increasing their antenna size rather than the number of reaction centers, thereby reducing their Fe demand. Here we provide physiological evidence that natural populations of Southern Ocean phytoplankton employ a similar photoacclimation strategy to cope with low ambient DFe concentrations. During a research cruise to the Ross Sea in 2013-2014, we conducted 4 bioassay experiments in which we manipulated light and DFe concentrations and measured changes in phytoplankton biomass, growth rate, photosynthetic parameters, fluorescence parameters, and pigment composition. Phytoplankton responded strongly to DFe additions, exhibiting significantly higher biomass, growth rates, and photosynthetic competency. At low light, the maximum photosynthetic rate $\left(P_{\max }^{*}\right)$ was significantly reduced and the photosynthetic efficiency $\left(\alpha^{*}\right)$ was unchanged compared to the high light treatment, regardless of phytoplankton species composition or DFe concentration. Our data suggest that Southern Ocean phytoplankton have evolved an Fe-saving strategy whereby they photoacclimate to low light by increasing their photosynthetic unit size, rather than photosynthetic unit number, even when DFe is available. It appears this Fe-saving strategy is characteristic of both Phaeocystis antarctica and diatoms, suggesting that it is a common adaptation among phytoplankton taxa that grow under Fe limitation in the Southern Ocean.
\end{abstract}

KEY WORDS: Phytoplankton $\cdot$ Photophysiology $\cdot$ Iron limitation $\cdot$ Ross Sea

\section{INTRODUCTION}

Coastal polynyas (areas of open water surrounded by ice) on the Antarctic continental shelf are some of the most biologically productive areas of the Southern Ocean (Arrigo \& van Dijken 2003, Arrigo et al. 2015). Due to their high rates of primary production,

${ }^{*}$ Corresponding author: arrigo@stanford.edu rapid organic matter sinking (DiTullio et al. 2000), and formation of dense bottom water, polynyas play a disproportionately important role in sequestering anthropogenic carbon dioxide $\left(\mathrm{CO}_{2}\right)$ (Arrigo et al. 2008). Of the approximately 50 coastal polynyas located along the Antarctic coast, the Ross Sea Polynya (RSP) is the largest and most productive, covering an 
area of $>400000 \mathrm{~km}^{2}$ in spring and accounting for more than half of the primary production in all Antarctic coastal polynyas combined (Arrigo \& van Dijken 2003, Arrigo et al. 2015).

Elucidating the relationship between phytoplankton photosynthetic rates, irradiance, and nutrient limitation is essential to understanding patterns of productivity in marine ecosystems (Barlow et al. 2010, Hoppe et al. 2017), as well as the potential effects of climate change on marine productivity. This is especially true in high latitude ecosystems, where changes in sea ice cover directly affect both the light penetration into the water column and the stratification patterns that control the mixed layer depth (MLD) and thus light availability for phytoplankton in the upper ocean (e.g. Stammerjohn et al. 2008, Montes-Hugo et al. 2009). Phytoplankton phenotypically respond to changes in their light environment through photoacclimation, which involves changes in the photosynthetic apparatus that in turn affect the photosynthesis versus irradiance $(P-E)$ relationship (see reviews by Falkowski \& LaRoche 1991, MacIntyre et al. 2002).

Low dissolved iron (DFe) concentrations limit phytoplankton photosynthesis and growth throughout much of the Southern Ocean (Martin et al. 1990, Boyd et al. 2007, 2012), including surface waters of the RSP (Bertrand et al. 2007, Sedwick et al. 2011, Rose et al. 2013, Gerringa et al. 2015). Fe limitation directly affects phytoplankton photosynthesis because components of the photosynthetic apparatus, such as the electron transport chain and reaction centers that contain photosynthetic pigments, are composed of macromolecules that contain Fe (Raven 1990). Therefore, Fe requirements of phytoplankton are thought to increase at low light when phytoplankton need more photosynthetic reaction centers to optimize light capture (Maldonado et al. 1999, Strzepek et al. 2012). However, Southern Ocean phytoplankton may have adapted to their low-Fe environment by evolving a strategy of increasing their antennae size at low light, which does not increase their Fe requirement, rather than increasing the number of photosynthetic units (Strzepek et al. 2012, RyanKeogh et al. 2017a).

Interestingly, $\mathrm{Fe}$ limitation has been reported to both reduce and enhance photodamage to photosystems at high light levels. Since Fe limited phytoplankton generally have decreased concentrations of photosynthetic pigments, fewer photons are absorbed when they are exposed to high light, and photodamage is decreased (Greene et al. 1992, van de Poll et al. 2005, van Leeuwe \& Stefels 2007). On the other hand, Fe limitation reduces the efficiency of electron transport downstream of photosystem II (PS II), which can enhance the formation of oxygen radicals and increase the potential for photodamage (Rochaix 2011).

Diatoms and the haptophyte Phaeocystis antarctica typically dominate the mixed phytoplankton assemblages in the Southern Ocean (Arrigo et al. 1999, Trimborn et al. 2017). Under laboratory conditions, these 2 taxa differ in their photosynthetic responses to light (Kropuenske et al. 2009, Arrigo et al. 2010, Mills et al. 2010, van de Poll et al. 2011) and Fe limitation (Alderkamp et al. 2011, Ryan-Keogh et al. 2017a, Strzepek et al. 2019). However, to date, field data from the Ross Sea have either not shown such taxonomic differences in responses to $\mathrm{Fe}$ and light (van Hilst \& Smith 2002, Robinson et al. 2003, Smith \& Donaldson 2015) or differences that were observed have been based primarily on measurements of fluorescence parameters alone (Ryan-Keogh et al. 2017a), rather than rates of carbon fixation. Thus, the aim of this study was to determine the effects of Fe limitation on the mode of photoacclimation of natural phytoplankton assemblages in the RSP that include diatoms and P. antarctica in the context of modes observed in other ocean regimes. This was achieved by performing bioassay experiments on waters dominated by both diatoms and P. antarctica under different DFe concentrations and light levels and measuring rates of growth, carbon fixation, nutrient utilization, as well as photophysiological parameters and pigment composition.

\section{MATERIALS AND METHODS}

\subsection{Sampling}

The Phantastic I cruise (NBP 13-10) sampled 33 stations within the RSP aboard the RVIB 'Nathaniel B. Palmer' during the austral spring and summer from 20 December 2013 to 5 January 2014. Typical sampling depths were 10, 25, 50, 75, $100 \mathrm{~m}$, and every $100 \mathrm{~m}$ thereafter in deeper waters on the shelf. Temperature, depth, and salinity were measured with an SBE 911plus CTD system (SeaBird Electronics). The frame was outfitted with a C-star transmissometer (WET Labs) and a chlorophyll a ( $\mathrm{chl}$ a) fluorometer (WET Labs).

Temperature and salinity are expressed as conservative temperature $\left({ }^{\circ} \mathrm{C}\right)$ and absolute salinity $\left(\mathrm{g} \mathrm{kg}^{-1}\right)$ according to McDougall et al. (2009). 


\subsection{Fe addition bioassay experiments}

We conducted bioassay experiments (Expts) at Stations 20, 33, 91, and 101 in the southwestern Ross Sea (Fig. 1). Large volumes of seawater ( 100 1) were collected at selected depths (Table 1) using a GEOTRACES-style non-contaminating CTD-Rosette deployed on a coated aramid cable with externallyclosing 12 l Go-Flo bottles (see Gerringa et al. 2015 for details).

Trace metal clean techniques were used throughout the bioassay experiments. Acid washed polycarbonate bottles (2 1) were rinsed 3 times with purified Milli-Q water (Millipore) and once with seawater from the same station before being filled to the brim with unfiltered seawater. Triplicate bottles for each treatment were incubated at in situ water temperature in transparent deck incubators under incident irradiance shaded with different levels of neutral transmission (i.e. wavelength independent) screening to achieve a high light (HL) treatment of $30 \%$ of surface photosynthetically active radiation (PAR) and a low light (LL) treatment of $3 \%$ of surface PAR. Consequently, mean daily PAR in the LL treatments ranged from 33 to $51 \mu \mathrm{mol}$ photons $\mathrm{m}^{-2} \mathrm{~s}^{-1}$ for the 4 experiments, similar to the depth-averaged value within a relatively deep (40 m) summer mixed layer (Alderkamp et al. 2010, 2011), while those in the HL treatments ranged from 331 to $512 \mu \mathrm{mol}$ photons $\mathrm{m}^{-2} \mathrm{~s}^{-1}$ (see Table 2), similar to values in Antarctic surface waters (Alderkamp et al. 2010, 2011).

Expts 1 and 2 included 4 different treatments, a LL control without added DFe (LL-Fe), a LL treatment with added DFe (LL+Fe), a HL control without added
DFe (HL-Fe), and a HL treatment with added DFe $(\mathrm{HL}+\mathrm{Fe})$. In Expts 3 and 4, 2 additional dark treatments were added to test the effects of prolonged darkness on phytoplankton, both without added DFe (D-Fe) and with added DFe (D+Fe). A sufficient amount of $\mathrm{FeCl}_{3}$ from a $1000 \times$ stock (in weakly acidified, $0.2 \mu \mathrm{m}$ filtered seawater) was added to the $+F$ e treatments to achieve a final DFe concentration of 4 nM (Mills et al. 2012, Alderkamp et al. 2015). Nothing was added to the control treatment. Bottles were capped and caps were wrapped with Parafilm to prevent contamination from seawater in the incubator. Water was sampled at the beginning of the experiment (Day 0) and each treatment was sampled at 4 and $6 \mathrm{~d}$, within $3 \mathrm{~h}$ of solar noon, for all parameters listed in Section 2.3. Based on continued uptake of nitrate $\left(\mathrm{NO}_{3}{ }^{-}\right)$after Day 4 (see Fig. 2), neither DFe nor $\mathrm{NO}_{3}{ }^{-}$had become limiting by Day 4 of the $6 \mathrm{~d}$ experiment, so unless otherwise noted, results are presented for samples collected on Day 4.

\subsection{Analytical methods}

\subsubsection{Nutrient concentrations}

Samples were collected directly from the experimental bottles, filtered through $0.2 \mu \mathrm{m}$ Acrodisk filters and stored at $-20^{\circ} \mathrm{C}$ for $\mathrm{NO}_{3}{ }^{-}$, nitrite $\left(\mathrm{NO}_{2}{ }^{-}\right)$, and phosphate $\left(\mathrm{PO}_{4}{ }^{3-}\right)$ analysis and $4^{\circ} \mathrm{C}$ for silicate $\left(\mathrm{Si}(\mathrm{OH})_{4}\right)$ analysis within 4 mo of collection. Concentrations of $\mathrm{NO}_{3}{ }^{-}, \mathrm{NO}_{2}{ }^{-}, \mathrm{PO}_{4}{ }^{3-}$ and $\mathrm{Si}(\mathrm{OH})_{4}$ were determined colorimetrically on a Bran en Luebbe trAAcs 800 Autoanalyzer (Grasshoff et al. 1983). Measurements were made simultaneously on 4 channels: $\mathrm{PO}_{4}{ }^{3-}$,

Table 1. Characteristics of stations where water was used to initiate bioassay experiments

\begin{tabular}{|c|c|c|c|c|}
\hline Parameter & $\begin{array}{l}\text { Expt } 1 \\
\text { Stn } 20\end{array}$ & $\begin{array}{l}\text { Expt } 2 \\
\text { Stn } 30\end{array}$ & $\begin{array}{l}\text { Expt } 3 \\
\text { Stn } 91\end{array}$ & $\begin{array}{c}\text { Expt } 4 \\
\text { Stn } 101\end{array}$ \\
\hline Latitude $\left({ }^{\circ} \mathrm{S}\right)$ & $77^{\circ} 00^{\prime}$ & $77^{\circ} 19^{\prime}$ & $77^{\circ} 00^{\prime}$ & $76^{\circ} 30^{\prime}$ \\
\hline Longitude $\left({ }^{\circ} \mathrm{E}\right)$ & $177^{\circ} 30.33^{\prime}$ & $177^{\circ} 30^{\prime}$ & $171^{\circ} 00^{\prime}$ & $171^{\circ} 00^{\prime}$ \\
\hline Sample depth (m) & 10.2 & 9.97 & 25.01 & 23.5 \\
\hline Temperature $\left({ }^{\circ} \mathrm{C}\right)$ & -0.73 & -0.99 & -0.52 & 0.94 \\
\hline Salinity & 34.43 & 34.40 & 34.43 & 34.41 \\
\hline $\mathrm{Chl} \mathrm{a}\left(\mathrm{mg} \mathrm{m}^{-3}\right)$ & 7.43 & 6.51 & 5.27 & 4.23 \\
\hline$\%$ Phaeocystis antarctica & 69 & 36 & 54 & 5 \\
\hline$\%$ Diatoms & 30 & 61 & 46 & 94 \\
\hline$\%$ Other phytoplankton & 1 & 3 & 0 & 1 \\
\hline $\mathrm{DFe}(\mathrm{nM})($ mean $\pm \mathrm{SD})$ & $0.086 \pm 0.013$ & $0.067 \pm 0.026$ & $0.090 \pm 0.012$ & $0.061 \pm 0.014$ \\
\hline $\mathrm{NO}_{3}^{-}(\mu \mathrm{M})$ & 20.3 & 23.2 & 21.7 & 17.7 \\
\hline $\mathrm{PO}_{4}^{3-}(\mu \mathrm{M})$ & 1.45 & 1.61 & 1.53 & 1.06 \\
\hline $\mathrm{Si}(\mathrm{OH})_{4}(\mu \mathrm{M})$ & 71.7 & 70.8 & 70.1 & 57.4 \\
\hline Mixed layer depth (m) & 50 & 38 & 12 & 19 \\
\hline Euphotic depth (m) & 24 & 22 & 23 & 32 \\
\hline
\end{tabular}




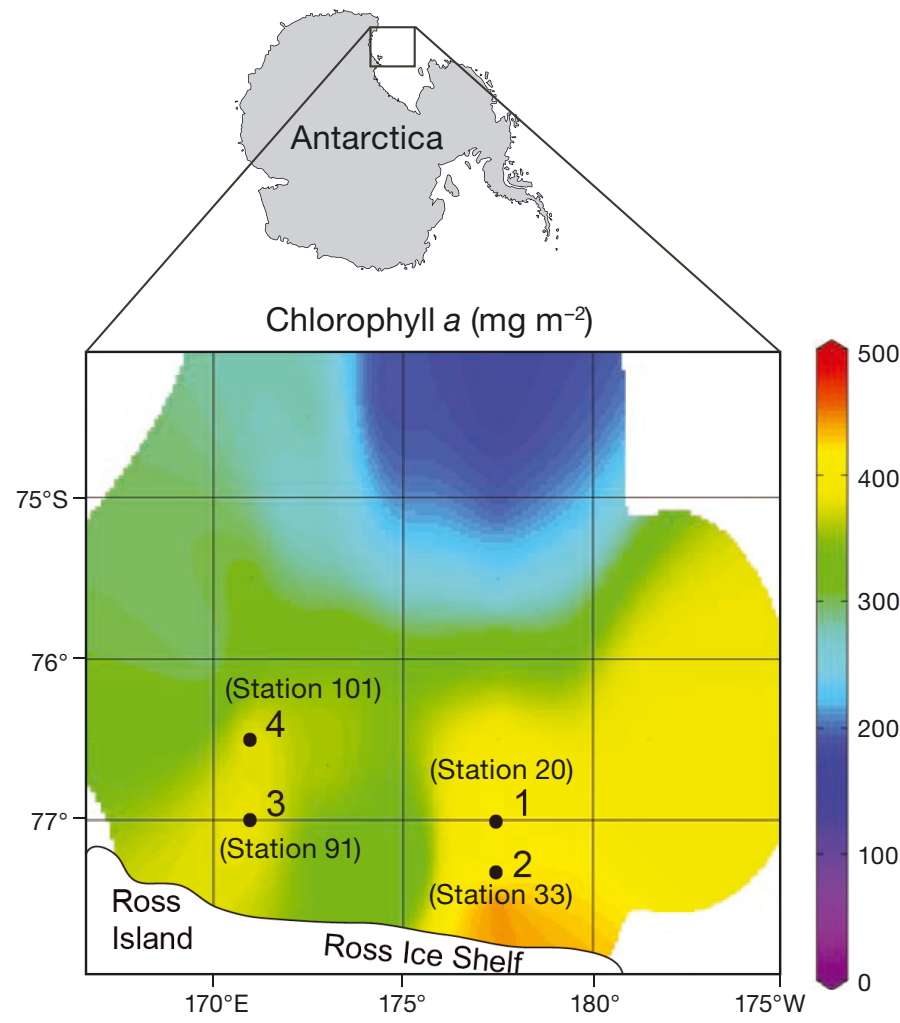

Fig. 1. Experiment locations in the southwestern Ross Sea within the Ross Sea Polynya. Colored background represents depth-integrated chl a

$\mathrm{Si}(\mathrm{OH})_{4}, \mathrm{NO}_{3}^{-}$and $\mathrm{NO}_{2}^{-}$together, and $\mathrm{NO}_{2}^{-}$separately. All measurements were calibrated with standards diluted in $0.2 \mu \mathrm{m}$-filtered low nutrient seawater, which was also used as wash-water between the samples. Detection limit, accuracy, and precision, respectively, of macronutrient determinations are as follows: $\mathrm{NO}_{3}{ }^{-}: 0.08,0.32$, and $0.07 \mu \mathrm{M}_{i} \mathrm{NO}_{2}^{-}: 0.006$, 0.02 , and $0.006 \mu \mathrm{M}_{i} \mathrm{PO}_{4}{ }^{3-}: 0.006,0.001$, and $0.01 \mu \mathrm{M}_{\text {; }}$ and $\mathrm{Si}(\mathrm{OH})_{4}: 0.06,0.037$, and $0.09 \mu \mathrm{M}$.

Concentrations of DFe from Day 0 samples were determined on board using Flow Injection Analysis (see Gerringa et al. 2015 for details). Random experimental and control incubation bottles were sampled at Day 0 and DFe was $0.05 \pm 0.03 \mathrm{nM}$, indicating no DFe contamination.

\subsubsection{Particulate organic carbon (POC) and particulate organic nitrogen (PON)}

Samples (100-1000 ml) were filtered onto precombusted $\left(450^{\circ} \mathrm{C}\right.$ for $\left.4 \mathrm{~h}\right) 25 \mathrm{~mm}$ Whatman GF/F filters and dried at $60^{\circ} \mathrm{C}$ for analysis of POC and PON on a Costech Elemental Analyzer using acetanilide as a calibration standard.

\subsubsection{Pigment analysis}

Triplicate samples (50-500 $\mathrm{ml}$ ) for determination of fluorometric chl a were filtered onto $25 \mathrm{~mm}$ Whatman $\mathrm{GF} / \mathrm{F}$ filters. Filters were extracted for $24 \mathrm{~h}$ at $4^{\circ} \mathrm{C}$ in $5 \mathrm{ml}$ of $90 \%$ acetone and analyzed on a Turner Model $10 \mathrm{AU}$ fluorometer before and after acidification (Holm-Hansen et al. 1965).

The full pigment composition was analyzed by HPLC. Samples (100-2000 ml) were filtered onto $25 \mathrm{~mm}$ Whatman GF/F filters, flash frozen in liquid nitrogen, and stored at $-80^{\circ} \mathrm{C}$ until analysis within 6 mo of collection. The filters for pigment analysis were then freeze-dried $(48 \mathrm{~h})$ and extracted in $90 \%$ acetone $\left(48 \mathrm{~h}\right.$ at $4^{\circ} \mathrm{C}$; van Leeuwe et al. 2006). Pigments were separated by HPLC (Waters 2695) with a Zorbax Eclipse XDB-C8 column (3.5 $\mu \mathrm{m}$ particle size) using the method of Van Heukelem \& Thomas (2001). Detection was based on retention time and diode array spectroscopy (Waters 996) at $436 \mathrm{~nm}$. Chl $a$, chl $b$, chl $c_{3}, 19^{\prime}$ butanoyloxyfucoxanthin (19'But), fucoxanthin (Fuco), 19' hexanoyloxyfucoxanthin (19'-Hex), diadinoxanthin (DD), diatoxanthin (DT), and $\beta$-carotene ( $\beta$-Car) were quantified manually using standards (DHI LAB products). Phytoplankton taxonomic composition was assessed using CHEMTAX (version 1.95) (Mackey et al. 1996) as described in Selz et al. (2018).

\subsubsection{Phytoplankton photosynthesis rates}

$P-E$ relationships were determined from pooled replicates (water from each of the triplicate bottles was combined) for each experimental treatment. $P-E$ relationships were determined using the ${ }^{14} \mathrm{C}$-bicarbonate incorporation technique by incubating twenty $2 \mathrm{ml}$ aliquots of seawater in a photosynthetron for $2 \mathrm{~h}$ over a range of light intensities from 3 to $542 \mu \mathrm{mol}$ photons $\mathrm{m}^{-2} \mathrm{~s}^{-1}$ at $0^{\circ} \mathrm{C}$ (Lewis \& Smith 1983; the full method is outlined in Arrigo et al. 2010). $\mathrm{CO}_{2}$ incorporation (photosynthetic rate) normalized by chl a concentration $\left(P^{*}\right)$ was calculated from ${ }^{14} \mathrm{C}$ incorporation and the data were fit by least squares nonlinear regression to the equation of Webb et al. (1974)

$$
P^{*}=P_{\max }^{*}\left[1-\exp \left(-\alpha^{*} \frac{E}{P_{\max }^{*}}\right)\right]
$$

where $P_{\max }^{*}$ is the maximum rate of photosynthesis $\left(\mathrm{CO}_{2}\right.$ incorporation in $\left.\mathrm{g} \mathrm{C} \mathrm{g}^{-1} \mathrm{chl} \mathrm{a} \mathrm{h}{ }^{-1}\right)$ and $\alpha^{*}$ is the photosynthetic efficiency (initial slope of the $P-E$ curve) $\left(\mathrm{g} \mathrm{C} \mathrm{g}^{-1} \mathrm{chl} \mathrm{a} \mathrm{h}^{-1} \text { [ } \mu \mathrm{mol} \text { photons } \mathrm{m}^{-2} \mathrm{~s}^{-1}\right]^{-1}$ ) 
where photosynthetic rates are light limited, and $\mathrm{E}$ is irradiance ( $\mu \mathrm{mol}$ photons $\mathrm{m}^{-2} \mathrm{~s}^{-1}$ ). The photoacclimation parameter $E_{\mathrm{k}}\left(\mu \mathrm{mol}\right.$ photons $\mathrm{m}^{-2} \mathrm{~s}^{-1}$ ) was calculated as $P_{\max }^{*} / \alpha^{*}$. $P-E$ data were also fitted to the model of Platt et al. (1980), which contains the photoinhibition parameter $\beta^{*}\left(\mathrm{~g} \mathrm{C} \mathrm{g}{ }^{-1} \mathrm{chl} \mathrm{a} \mathrm{h}^{-1}\right.$ [ $\mathrm{\mu mol}$ photons $\mathrm{m}^{-2} \mathrm{~s}^{-1} \mathrm{~J}^{-1}$ ). However, $\beta^{*}$ was not significantly different from zero in any of the $P-E$ curves; therefore, this model was disregarded.

\subsubsection{Phytoplankton absorption}

The mean chl a-specific absorption coefficient $\bar{a}^{*}$, $\mathrm{m}^{2} \mathrm{mg}^{-1} \mathrm{chl}$ a) was determined from pooled replicates for each bioassay treatment. Aliquots of the seawater sample (100-1000 ml) were filtered onto $25 \mathrm{~mm}$ Whatman GF/F filters for measurement of the absorption spectra (300-800 $\mathrm{nm}$ ) for particulates $\left(a_{\mathrm{p}}\right)$ and detritus $\left(a_{\text {det }}\right)$ on a Perkin-Elmer Lambda 35 spectrophotometer equipped with an integrating sphere (Labsphere) using the filter pad method and optical corrections in Mitchell \& Kiefer (1988) and the coefficients of Bricaud \& Stramski (1990). Detrital absorption was assayed after methanol extraction according to the method of Kishino et al. (1985). Chl aspecific absorption by phytoplankton $\left(a_{\mathrm{ph}}^{*}\right)$ at each wavelength $(\lambda)$ was calculated as

$$
a_{\mathrm{ph}}^{*}(\lambda)=\frac{a_{\mathrm{p}}(\lambda)-a_{\mathrm{det}}(\lambda)}{[\operatorname{chl} a]}
$$

where $[\mathrm{chl} \mathrm{a}]$ is the chl a concentration of the sample. $\bar{a}^{*}$ was calculated using the equation

$$
\bar{a}^{*}=\frac{\sum_{400}^{700} a_{\mathrm{ph}}^{*} E(\lambda)}{\sum_{400}^{700} E(\lambda)}
$$

where $E(\lambda)$ ( $\mu \mathrm{mol}$ photons $\mathrm{m}^{-2} \mathrm{~s}^{-1}$ ) is the spectral irradiance of the photosynthetron light source.

\subsubsection{Quantum yield of photosynthesis}

The quantum yield of photosynthesis $\left(\Phi_{\mathrm{m}}\right.$, mol C $\mathrm{mol}^{-1}$ photons absorbed) was calculated as

$$
\Phi_{\mathrm{m}}=\frac{\alpha^{*}}{43 \bar{a}^{*}}
$$

after first confirming that $\Phi_{\mathrm{m}}$ was maximal at the lowest light level used in each of the assays (Johnson \& Barber 2003).

\subsubsection{Variable fluorescence}

A Satlantic Fluorescence Induction and Relaxation (FIRe) system was used to determine the maximum photochemical efficiency $\left(F_{\mathrm{v}} / F_{\mathrm{m}}\right)$ and functional absorption cross-section $\left(\sigma_{\text {PSII }}\right)\left(\AA^{2}\right.$ photon $\left.^{-1}\right)$ of PS II (Gorbunov et al. 1999). Prior to analysis, the FIRe was blanked with GF/F-filtered seawater from the same station. After removal from the sample bottles, samples were acclimated in the dark at $2^{\circ} \mathrm{C}$ for $30 \mathrm{~min}$ to fully oxidize the photosynthetic reaction centers before analysis on the FIRe.

\subsection{Statistical analysis}

All statistical tests were done using the statistical software package R (version 3.5.3). Normality was tested using the Shapiro-Wilk normality test and equality of variances was determined using the F-test. Effects of DFe addition at each light level and differences between experiments were tested using 1-way ANOVA. Effects of DFe addition, light level, and their interactions on phytoplankton parameters were tested in all experiments combined using 2-way ANOVA analysis. When parameters differed between experiments based on the 1-way ANOVA, responses were normalized to the LL-Fe treatment to compensate for differences between experiments. However, this did not affect the outcome of the 2-way ANOVAs. Differences were considered significant at $\mathrm{p}<0.05$.

\section{RESULTS}

\subsection{Overview of hydrography and phytoplankton bloom in the RSP}

At the time of our study, surface waters of the RSP were ice free and dominated by Antarctic Surface Water. These waters are characterized by a temperature exceeding $-1.85^{\circ} \mathrm{C}$ and a neutral density of $<28 \mathrm{~kg} \mathrm{~m}^{-3}$ (Tomczak \& Godfrey 2001, Orsi \& Wiederwohl 2009). The temperature of the water used for our 4 bioassay experiments varied over a modest range of approximately -1 to $1^{\circ} \mathrm{C}$ (Table 1 ). MLD was highly variable throughout the RSP, with deep mixed layers $(30-80 \mathrm{~m})$ in the central RSP and shallow mixed layers $(<20 \mathrm{~m})$ in the western and southwestern RSP. At the 4 locations where water was collected for our bioassay experiments, MLD varied from 12 to $50 \mathrm{~m}$ (Table 1).

Macronutrients in the RSP showed signs of depletion by phytoplankton at the time of sampling, with 
concentrations of $\mathrm{NO}_{3}{ }^{-}, \mathrm{PO}_{4}{ }^{3-}$, and $\mathrm{Si}(\mathrm{OH})_{4}$ decreasing from $31,2.1$, and $85 \mu \mathrm{M}$ below the mixed layer to $18-$ $23,1.1-1.6$, and $57-72 \mu \mathrm{M}$ in near-surface waters, respectively (Table 1). However, macronutrient concentrations in surface waters were still sufficiently high that they would not be expected to limit phytoplankton growth rates. In contrast, DFe concentrations were remarkably low throughout the upper mixed layer of the RSP (0.06-0.09 nM) (Table 1). Concentrations of DFe began to increase with depth at approximately $200 \mathrm{~m}$ in the vicinity of stations 20 (Expt 1) and 33 (Expt 2) and at $400 \mathrm{~m}$ near the deeper stations 91 (Expt 3) and 101 (Expt 4), eventually reaching concentrations of $0.5-2.3 \mathrm{nM}$ in near-bottom waters (Gerringa et al. 2015).

The 4 bioassay experiments were performed during a phytoplankton springsummer bloom, with surface chl a concentrations of $4.2-7.4 \mathrm{mg} \mathrm{m}^{-3}$ (Table 1). Phytoplankton biomass was highest in the southern portion of the RSP where the bioassay experiments were initiated (Fig. 1). According to our CHEMTAX analysis, the phytoplankton assemblage at the sampling location where the bioassays were conducted was mostly a mixture of diatoms and Phaeocystis antarctica, with the exception of Expt 4, which was overwhelmingly dominated by diatoms (Table 1).

\subsection{Phytoplankton responses to DFe and light: growth}

With the exception of the D treatments, which were kept in the dark, phytoplankton biomass measured as POC increased by a factor of 2 to 4 in all treatments in all 4 bioassay experiments (Fig. 2A, $\mathrm{C}, \mathrm{E}, \mathrm{G}$ ). Increases in POC were greater in the HL treatments than the LL treatments $(p<$ $0.05)$, regardless of whether or not DFe was added. However, at a given light treatment (LL or HL), the increase in POC was always greatest when DFe was added $(\mathrm{p}<0.05)$. We detected no interactive effects on POC increases between the light and DFe treatments.

Phytoplankton growth rates derived from the change in POC concentrations over time (Day 0-6) were higher in the HL treatment than in the LL treatment and higher in the $+\mathrm{Fe}$ treatments than in the unamended controls $(-\mathrm{Fe})$ in all 4 experiments (Table 2), suggesting that DFe availability limited phytoplankton growth in all experiments. Growth rates in the D treatments were negative (Table 2) due to phytoplankton loss exceeding growth. Growth rates in the HL and LL treatments differed between experiments $(p<0.05)$, with the highest growth rates observed in Expts 1 and 2 and the lowest growth rate in the diatom-dominated Expt 4.

Concurrent with the increase in phytoplankton biomass, $\mathrm{NO}_{3}{ }^{-}$decreased over time in all but the $\mathrm{D}$ treatments (Fig. 2B, $\mathrm{D}, \mathrm{F}, \mathrm{H}$ ), although we detected no interactive effects on $\mathrm{NO}_{3}{ }^{-}$between light and $\mathrm{DFe}$ (Table 3). The $\mathrm{NO}_{3}{ }^{-}$drawdown was proportional to
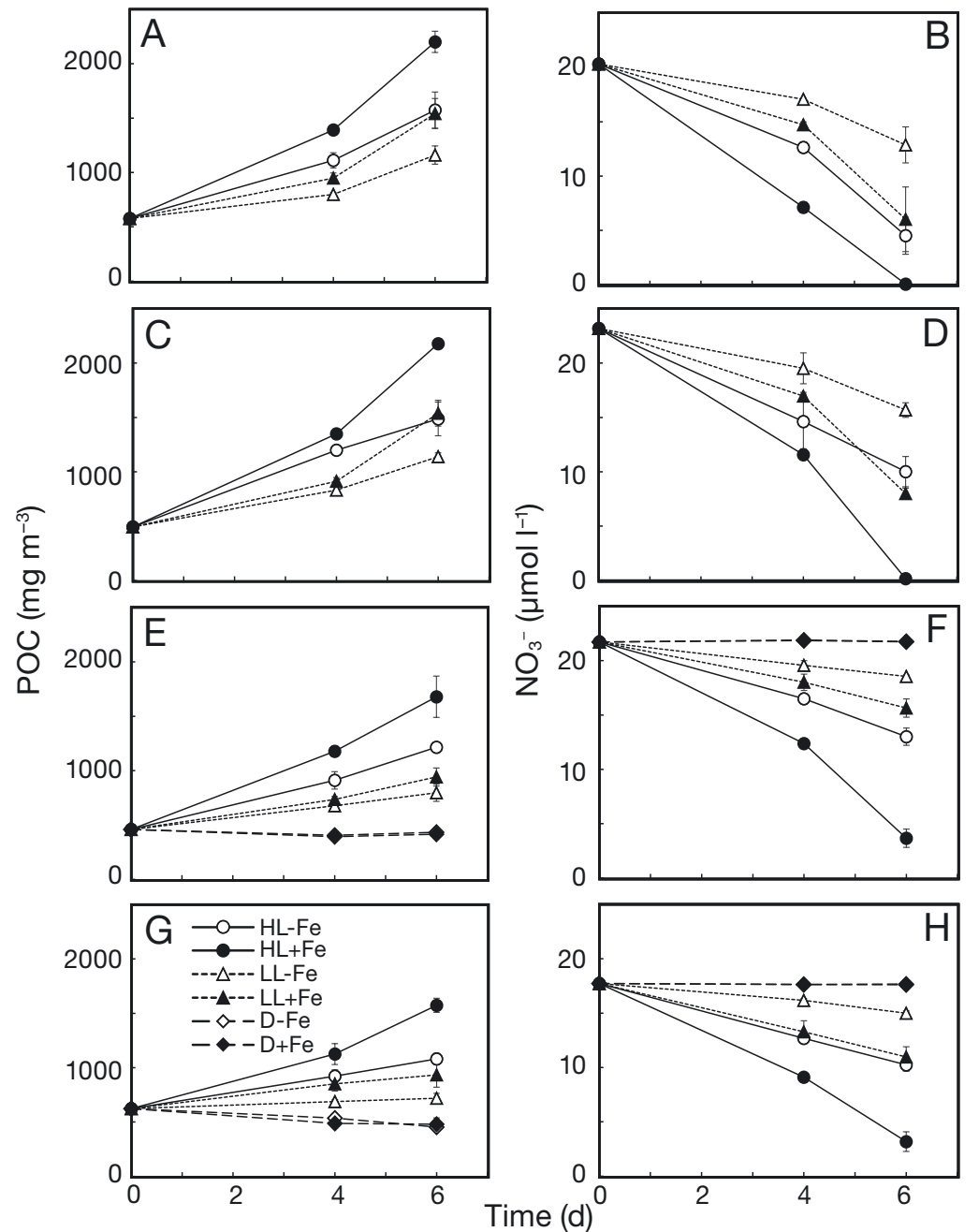

Fig. 2. Phytoplankton responses to dissolved iron (DFe) addition (solid symbols) in high light $(\mathrm{HL}+\mathrm{Fe})$, low light $(\mathrm{LL}+\mathrm{Fe})$, and dark $(\mathrm{D}+\mathrm{Fe})$ treatments compared to high light (HL-Fe), low light (LL-Fe), and dark (D-Fe) controls (open symbols). Shown are the mean concentrations of particulate organic carbon (POC) and $\mathrm{NO}_{3}{ }^{-}$, respectively, for $(\mathrm{A}, \mathrm{B})$ Expt 1, $(\mathrm{C}, \mathrm{D})$ Expt 2, $(\mathrm{E}, \mathrm{F})$ Expt 3, and $(\mathrm{G}, \mathrm{H})$ Expt 4 . Error bars: SD (triplicate incubations) 
the increase in POC and was greater in the HL treatments than the LL treatments $(p<0.05)$ and higher for a given light treatment when DFe was added $(\mathrm{p}$ $<0.05) . \mathrm{NO}_{3}{ }^{-}$was completely exhausted in the HL+Fe treatments of Expts 1 and 2 by Day 6. There was no difference in $\mathrm{NO}_{3}{ }^{-}$drawdown for a given treatment among the 4 experiments ( $p>0.05)$.

The POC/chl a ratio of the phytoplankton biomass and associated particulate matter ranged from 55 to 207 (wt/wt) (Table 2). The $\mathrm{POC} / \mathrm{chl}$ a ratio was significantly higher $(p<0.05)$ in the HL treatments than in the LL and D treatments (Table 3). However, DFe addition did not affect the POC/chl a ratio, nor was there an interactive effect between DFe and light. There was no difference in the $\mathrm{POC} / \mathrm{chl}$ a ratio among the 4 experiments.

The POC/PON (mol/mol) ratio of the phytoplankton biomass and associated particulate matter ranged from 6.0 to 7.8 (Table 2). DFe addition affected the POC/PON ratio, which was significantly lower than in the unamended controls (Table 3). On the other hand, the light treatment did not affect the POC/PON ratio and there was no interactive effect between DFe and light. There was no difference in the $\mathrm{POC} / \mathrm{PON}$ ratio among experiments.
Table 2. Experimental data measured during incubations. Data are means (SD) from triplicate bottles. I: value at start of the experiment. HL, LL, D: high light, low light, and dark treatments, respectively. + Fe and $-F e$ indicate iron addition and no iron addition treatments, respectively. PAR: photosynthetically available radiation; POC (PON): particulate organic carbon (nitrogen); chl a: chlorophyll a concentration; nd: no data collected for this treatment

\begin{tabular}{|c|c|c|c|c|}
\hline Treatment & Expt 1 & Expt 2 & Expt 3 & Expt 4 \\
\hline \multicolumn{5}{|c|}{ Mean PAR ( $\mu$ mol photons $\mathrm{m}^{-2} \mathrm{~s}^{-1}$ ) } \\
\hline Surface & 1104 & 1147 & 1708 & 1660 \\
\hline HL & 331 & 344 & 512 & 498 \\
\hline LL & 33 & 34 & 51 & 50 \\
\hline D & nd & nd & 0 & 0 \\
\hline \multicolumn{5}{|c|}{ POC-based growth rate $\left(\mathrm{d}^{-1}\right)$ Day 0-6 } \\
\hline $\mathrm{HL}-\mathrm{Fe} \quad \mathrm{C}$ & $0.169(0.016)$ & $0.168(0.021)$ & $0.159(0.010)$ & $0.091(0.008)$ \\
\hline $\mathrm{HL}+\mathrm{Fe}$ & $0.225(0.008)$ & $0.245(0.005)$ & $0.206(0.021)$ & $0.156(0.010)$ \\
\hline LL-Fe & $0.124(0.015)$ & $0.141(0.007)$ & $0.092(0.011)$ & $0.024(0.005)$ \\
\hline $\mathrm{LL}+\mathrm{Fe}$ & $0.180(0.021)$ & $0.208(0.020)$ & $0.120(0.011)$ & $0.067(0.013)$ \\
\hline $\mathrm{D}-\mathrm{Fe}$ & nd & nd & $-0.011(0.008)$ & $-0.040(0.005)$ \\
\hline $\mathrm{D}+\mathrm{Fe}$ & nd & nd & $-0.017(0.007)$ & $-0.036(0.008)$ \\
\hline \multicolumn{5}{|c|}{ POC/chl a (wt:wt) } \\
\hline I & 78 & 76 & 87 & 147 \\
\hline $\mathrm{HL}-\mathrm{Fe}$ & $118(13)$ & $129(7)$ & $185(17)$ & 207 (19) \\
\hline $\mathrm{HL}+\mathrm{Fe}$ & $114(8)$ & $112(7)$ & $182(31)$ & $160(5)$ \\
\hline LL-Fe & $70(2)$ & $71(5)$ & $107(4)$ & $138(19)$ \\
\hline $\mathrm{LL}+\mathrm{Fe}$ & $62(3)$ & $55(2)$ & 77 (3) & $78(17)$ \\
\hline $\mathrm{D}-\mathrm{Fe}$ & nd & nd & $105(7)$ & $168(17)$ \\
\hline $\mathrm{D}+\mathrm{Fe}$ & nd & nd & $97(6)$ & $150(13)$ \\
\hline \multicolumn{5}{|c|}{ POC/PON (mol:mol) } \\
\hline I & 6.8 & 7.1 & 6.9 & 6.0 \\
\hline $\mathrm{HL}-\mathrm{Fe}$ & $7.3(0.2)$ & $7.1(0.3)$ & $7.8(0.3)$ & $6.3(0.5)$ \\
\hline $\mathrm{HL}+\mathrm{Fe}$ & $6.8(0.4)$ & $6.9(0.0)$ & $7.2(0.2)$ & $6.4(0.1)$ \\
\hline LL-Fe & $7.1(0.0)$ & $7.2(0.1)$ & $7.6(0.1)$ & $6.6(0.1)$ \\
\hline $\mathrm{LL}+\mathrm{Fe}$ & $6.7(0.1)$ & $6.6(0.1)$ & $7.0(0.2)$ & $6.0(0.2)$ \\
\hline $\mathrm{D}-\mathrm{Fe}$ & nd & nd & $7.2(0.4)$ & $6.3(0.2)$ \\
\hline $\mathrm{D}+\mathrm{Fe}$ & nd & nd & $7.0(0.5)$ & $6.2(0.3)$ \\
\hline
\end{tabular}

\subsection{Phytoplankton responses to DFe and light: photosynthesis}

\subsubsection{Variable fluorescence}

$F_{\mathrm{v}} / F_{\mathrm{m}}$ ranged from 0.17 to 0.41 (Fig. 3A-D) and responded significantly to both the DFe and the light treatments, but we detected no interactive effects (Table 3). DFe addition resulted in an increase in $F_{\mathrm{v}} / F_{\mathrm{m}}$ in all light treatments in all experiments relative to the unamended controls $(\mathrm{p}<0.05)$. Light affected $F_{\mathrm{v}} / F_{\mathrm{m}}$ in all experiments $(\mathrm{p}<0.05)$, with $F_{\mathrm{v}} / F_{\mathrm{m}}$ being generally lower in the HL treatments than in the LL or D treatments. $F_{\mathrm{v}} / F_{\mathrm{m}}$ of the initial sample and $-\mathrm{Fe}$ treatments were similar, suggesting that the $F_{\mathrm{v}} / F_{\mathrm{m}}$ of in situ phytoplankton was depressed by lack of DFe availability. The $F_{\mathrm{v}} / F_{\mathrm{m}}$ in the D treatments remained similar to the initial $F_{\mathrm{v}} / F_{\mathrm{m}}$ after $4 \mathrm{~d}$.
At Day $6, F_{\mathrm{v}} / F_{\mathrm{m}}$ had decreased slightly in the D treatments, but remained within the range of all other incubations (results not shown), suggesting that phytoplankton maintained an active PS II even after $6 \mathrm{~d}$ of darkness. The $F_{\mathrm{v}} / F_{\mathrm{m}}$ did not differ significantly among the 4 experiments ( $\mathrm{p}>0.05)$ (Table 3 ).

The $\sigma_{\text {PSII }}$ ranged from 422 to $675 \AA$ photon $^{-1}$ (Fig. 3E-H) and there was no significant effect of either DFe or light treatments (Table 3). DFe effects on $\sigma_{\text {PSII }}$ in the individual experiments were generally minor and differed between experiments (Fig. 3E$\mathrm{H})$. DFe addition decreased $\sigma_{\mathrm{PSII}}$ slightly when compared to the unamended control in the LL treatment of Expt 1, the D treatment of Expt 3 and the HL treatment of Expt $4(\mathrm{p}<0.05)$. On the other hand, DFe addition increased $\sigma_{\text {PSII }}$ slightly when compared to the unamended control in the LL treatment of Expt 3 $(p<0.05)$. In other treatments, there was no effect of 


\begin{tabular}{|c|c|c|c|c|}
\hline Parameter & Expt & $\mathrm{DFe}$ & Light & DFe $\times$ Light \\
\hline chl $a$ increase & & - & - & \\
\hline POC increase & & - & - & \\
\hline $\mathrm{NO}_{3}{ }^{-}$drawdown & & $\bullet$ & $\bullet$ & \\
\hline $\mathrm{POC} / \mathrm{chl} a$ & & & - & \\
\hline $\mathrm{POC} / \mathrm{PON}$ & & $\bullet$ & & \\
\hline$F_{\mathrm{v}} / F_{\mathrm{m}}$ & & $\bullet$ & $\bullet$ & \\
\hline$\sigma_{\mathrm{PSII}}$ & - & & & \\
\hline$P_{\max }^{*}$ & & - & - & - \\
\hline$\alpha^{*}$ & & $\bullet$ & & \\
\hline$E_{\mathrm{k}}$ & & & $\bullet$ & \\
\hline$\overline{\mathrm{a}}^{*}$ & $\bullet$ & $\bullet$ & & \\
\hline$\Phi_{\mathrm{m}}$ & & $\bullet$ & & \\
\hline chl $c_{3} / \mathrm{chl} \mathrm{a}$ & $\bullet$ & & & \\
\hline 19' Hex/chl a & $\bullet$ & $\bullet$ & & \\
\hline Fuco/chl a & $\bullet$ & & & \\
\hline$\beta$-Car/chl a & & - & - & \\
\hline$(\mathrm{DD}+\mathrm{DT}) / \mathrm{chl} a$ & & & $\bullet$ & \\
\hline $\mathrm{PPp} / \mathrm{PSp}$ & & & $\bullet$ & \\
\hline
\end{tabular}

Table 3. Treatment effects on phytoplankton characteristics at Day 4 of bioassay experiments when analyzed using 2-way ANOVA. Effects are shown among experiments, DFe treatments, light treatments, and the interaction between DFe and light. $\bullet$ : significant effects at the $\mathrm{p}<0.05$ level. POC (PON): particulate organic carbon (nitrogen); chl a $\left(b, c_{3}\right)$ : chlorophyll a $\left(b, c_{3}\right)$ concentration; $F_{\mathrm{v}} / F_{\mathrm{m}}$ : maximum photochemical efficiency; $\sigma_{\mathrm{PSII}}$ : effective absorption cross section $\left(\AA^{2}\right.$ photon $\left.^{-1}\right) ; P_{\text {max }}^{*}$ : maximum chl a-normalized photosynthetic rate $\left(\mathrm{g} \mathrm{C}^{-1} \mathrm{chl} \mathrm{a} \mathrm{h}^{-1}\right) ; \alpha^{*}$ : photosynthetic efficiency ( $\mathrm{g} \mathrm{C} \mathrm{g}^{-1} \mathrm{chl} \mathrm{a} \mathrm{h}^{-1}$ [ $\mu \mathrm{mol}$ photons $\left.\left.\mathrm{m}^{-2} \mathrm{~s}^{-1}\right]^{-1}\right) ; E_{\mathrm{k}}$ : photoacclimation parameter ( $\mu \mathrm{mol}$ photons $\mathrm{m}^{-2} \mathrm{~s}^{-1}$ ); $\overline{\mathrm{a}}^{*}$ : mean chl $a$-specific absorption coefficient $\left(\mathrm{m}^{2} \mathrm{mg}^{-1} \mathrm{chl} a\right)_{;} \Phi_{\mathrm{m}}$ : quantum yield of photosynthesis (mol C mol-1 photons absorbed); Fuco: fucoxanthin; 19'-Hex: 19' hexanoyloxyfucoxanthin; DD: diadinoxanthin; DT: diatoxanthin; $\beta$-Car: $\beta$-carotene; PPp: photoprotective pigments; $\mathrm{PSp}$ : photosynthetic pigments
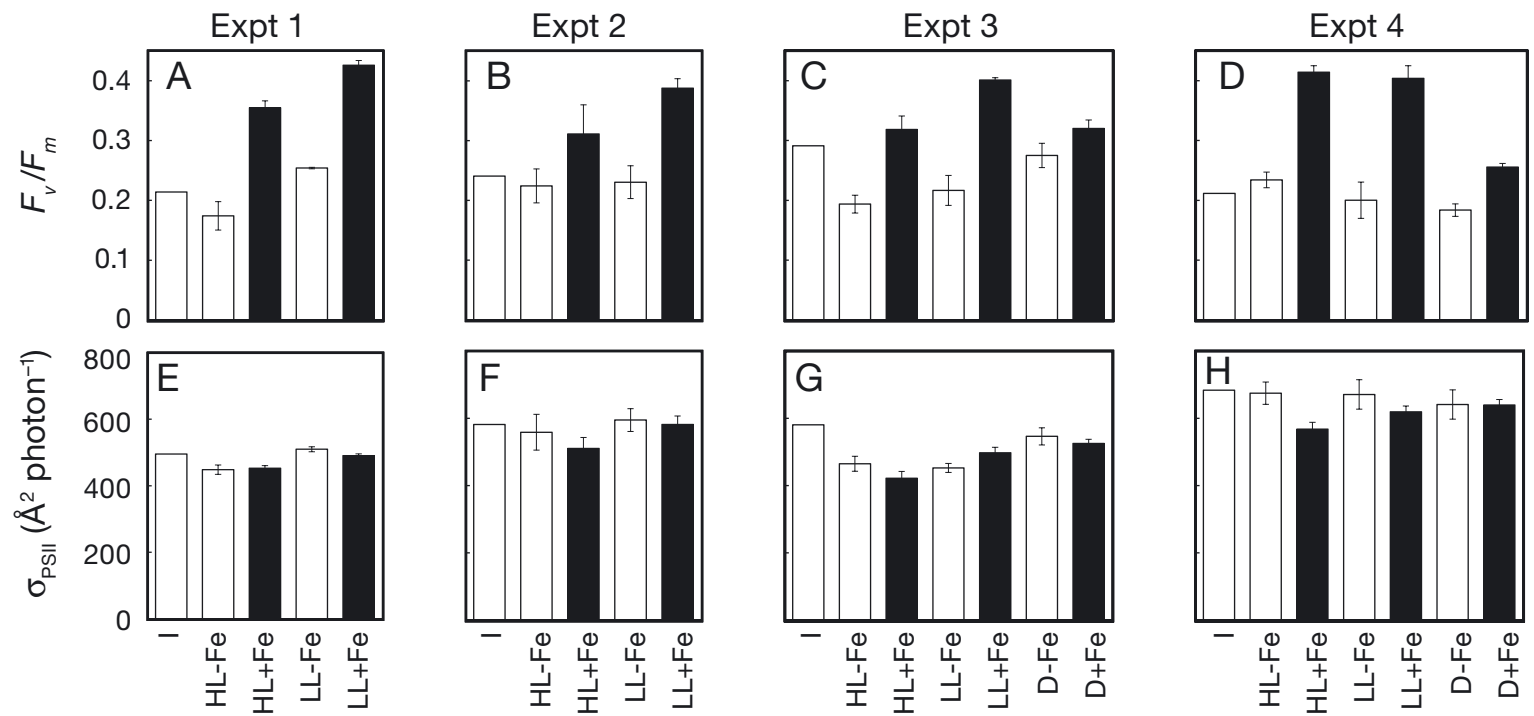

Fig. 3. Variable fluorescence at the start of the experiment (I) and responses to DFe addition after $4 \mathrm{~d}$ in high light (HL), low light $(\mathrm{LL})$, and dark (D) treatments. Mean and standard deviations of triplicate incubations of unamended controls (-Fe, white bars) and $\mathrm{DFe}$ additions $\left(+\mathrm{Fe}\right.$, black bars) are shown for $(\mathrm{A}-\mathrm{D})$ maximum photochemical efficiency $\left(F_{\mathrm{v}} / F_{\mathrm{m}}\right)$ and $(\mathrm{E}-\mathrm{H})$ effective absorption cross section of PS II ( $\left.\sigma_{\mathrm{PSII}}\right)$

DFe additions on $\sigma_{\mathrm{PSII}}$. The $\sigma_{\mathrm{PSII}}$ in D treatments was similar to that in HL and LL treatments, suggesting that the architecture of PS II was not altered when phytoplankton resided in the dark for 4 (Fig. 3E-H) or $6 \mathrm{~d}$ (results not shown). The $\sigma_{\mathrm{PSII}}$ differed among experiments (Table 3 ), with lower $\sigma_{\mathrm{PSII}}$ in Expts 1 and 3 , where $P$. antarctica dominated the phytoplankton assemblage, than in Expts 2 and 4 that were dominated by diatoms (Table 1 ). The highest $\sigma_{\text {PSII }}$ was found in Expt 4, where diatoms accounted for $94 \%$ of the phytoplankton assemblage.

\subsection{2. $P-E$ parameters}

$P_{\text {max }}^{*}$ ranged from 0.6 to $3.3 \mathrm{~g} \mathrm{C} \mathrm{g}^{-1} \mathrm{chl} \mathrm{a} \mathrm{h}^{-1}$ across all 4 experiments. $P_{\max }^{*}$ was significantly higher in the HL than the LL treatments $(\mathrm{p}<0.05)$. In addition, $P_{\max }^{*}$ was consistently higher in the $+\mathrm{Fe}$ treatments compared to the unamended controls in all experiments, except for the D treatments that exhibited slightly lower values for $P_{\max }^{*}$ (Fig. 4A-D). There was an interactive effect of $\mathrm{DFe}$ and light on $P_{\max }^{*}$ (Table 3), whereby DFe addition resulted in greater 

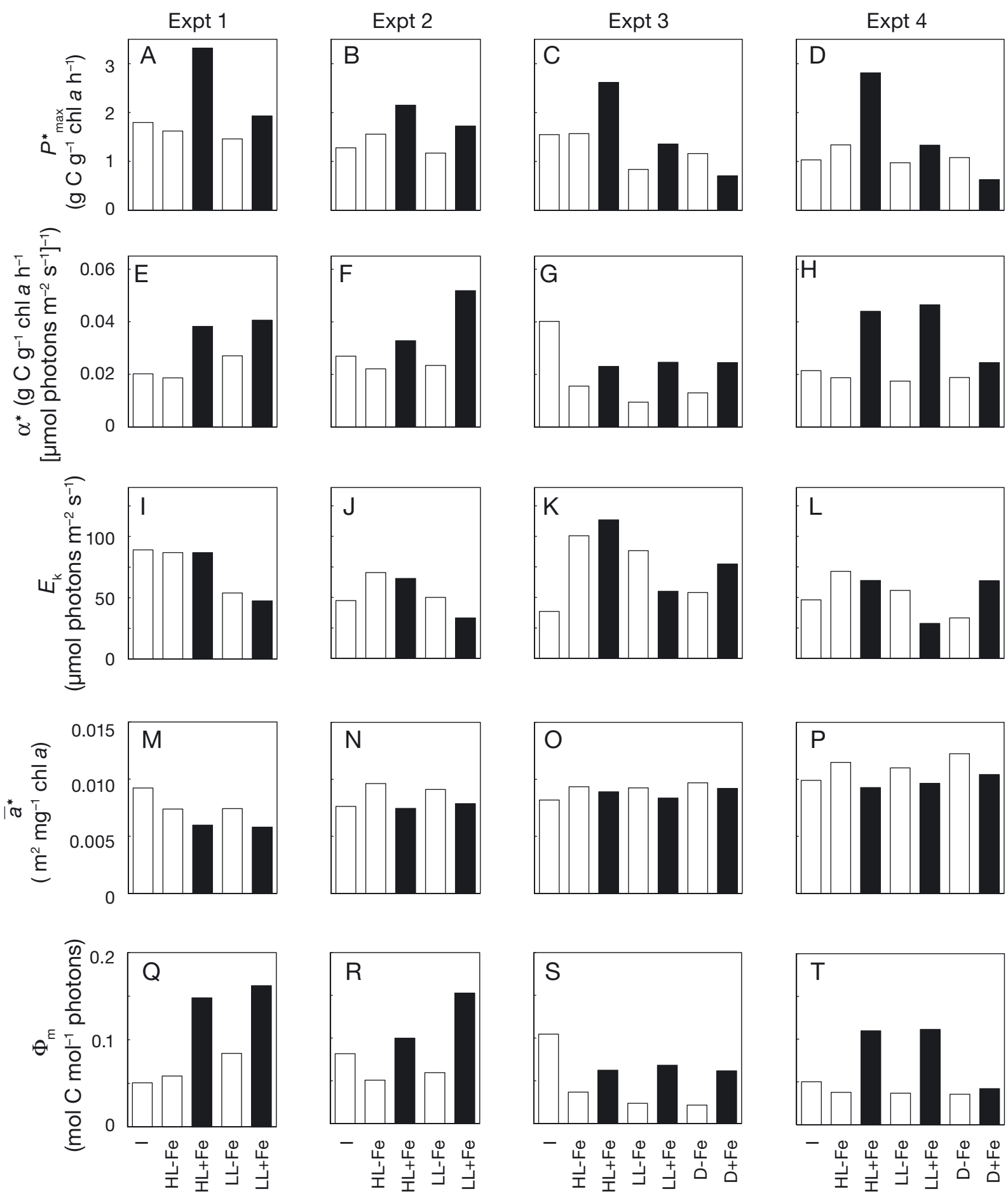

Fig. 4. Photosynthetic parameters at the start of the experiment (I) and responses to DFe addition after $4 \mathrm{~d}$ in high light (HL), low light (LL), and dark (D) treatments. Mean and standard deviations of triplicate incubations of unamended controls (-Fe, white bars) and DFe additions (+Fe, black bars) are shown for (A-D) maximum rate of photosynthesis $\left(P_{\max }^{*}\right),(\mathrm{E}-\mathrm{H})$ light limited rate of photosysnthesis $\left(\alpha^{*}\right)$, (I-L) photoacclimation parameter $\left(E_{\mathrm{k}}\right),(\mathrm{M}-\mathrm{P})$ phytoplankton mean specific absorption coefficient $\left(\bar{a}^{*}\right)$, and $(\mathrm{Q}-\mathrm{T})$ maximum quantum yield of photosynthesis $\left(\Phi_{\mathrm{m}}\right)$

increases in $P_{\max }^{*}$ in the HL treatment than in the LL and D treatments. $P_{\max }^{*}$ in D treatments was slightly lower than the range of $P_{\max }^{*}$ of the HL and
LL treatments, suggesting that maximum photosynthetic rates decreased slightly when phytoplankton resided in the dark for $4 \mathrm{~d}$, but photosynthesis re- 
mained active. The same was observed after $6 \mathrm{~d}$ (results not shown). $P_{\max }^{*}$ did not differ significantly between experiments $(\mathrm{p}>0.05)$.

$\alpha^{*}$ ranged from 0.009 to $0.052 \mathrm{~g} \mathrm{C} \mathrm{g}^{-1} \mathrm{chl} \mathrm{a} \mathrm{h}^{-1}$ ( $\mu \mathrm{mol}$ photons $\left.\mathrm{m}^{-2} \mathrm{~s}^{-1}\right)^{-1}$ across all experiments, being higher in $+\mathrm{Fe}$ treatments than in the unamended controls in all light treatments (Fig. 4E-H). On the other hand, there was no effect of the light treatment on $\alpha^{*}$ (Table 3), suggesting that the efficiency of photosynthesis at low light did not increase after $4 \mathrm{~d}$ under LL conditions, relative to HL conditions. We did not detect any interactions between DFe and light treatment on $\alpha^{*}$ (Table 3). $\alpha^{*}$ in $\mathrm{D}$ treatments was within the range of $\alpha^{*}$ of the HL and LL treatments, suggesting that the efficiency of photosynthesis at low light remained unchanged when phytoplankton resided in the dark for 4 or $6 \mathrm{~d}$ (results not shown). $\alpha^{*}$ did not differ significantly among experiments (Table 3 ).

$E_{\mathrm{k}}$ ranged from 29 to $113 \mu \mathrm{mol}$ photons $\mathrm{m}^{-2} \mathrm{~s}^{-1}$ across all experiments, and there was no DFe effect on $E_{\mathrm{k}}$ (Fig. 4I-L), since DFe additions increased both $P_{\max }^{*}$ and $\alpha^{*}$ proportionally $\left(E_{\mathrm{k}}=P_{\max }^{*} / \alpha^{*}\right)$. On the other hand, there was a clear light effect on $E_{\mathrm{k}}(\mathrm{p}<$ 0.05 ), with higher $E_{\mathrm{k}}$ in the HL treatments than in the LL and D treatments. This is because $P_{\max }^{*}$ was higher in the HL treatments, whereas there was no light effect on $\alpha^{*} . E_{\mathrm{k}}$ in the D treatments was within the range of that of HL and LL treatments, suggesting that the light acclimation properties of phytoplankton remained unchanged when phytoplankton resided in the dark for 4 or $6 \mathrm{~d}$ (results not shown). $E_{\mathrm{k}}$ did not differ significantly among experiments (Table 3 ) $\bar{a}^{*}$ ranged from 0.007 to 0.012 (Fig. 4M-P) across all experiments and was reduced by DFe addition but unaffected by light treatment (Table 3). $\bar{a}^{*}$ in D treatments was similar to HL and LL treatments, suggesting that the architecture of photosystems remained unchanged when phytoplankton resided in the dark for $4 \mathrm{~d}$ (Fig. $4 \mathrm{M}-\mathrm{P}$ ) or $6 \mathrm{~d}$ (results not shown). $\bar{a}^{*}$ differed between the 4 experiments $(\mathrm{p}<0.05)$, being smallest in Expt 1 , which was dominated by $P$. antarctica, and largest in Expt 4, which was dominated by diatoms.

$\Phi_{\mathrm{m}}$ ranged from 0.021 to $0.16 \mathrm{~mol} \mathrm{C} \mathrm{mol}^{-1}$ photons (Fig. 4Q-T) across all 4 experiments and was significantly higher in the $+\mathrm{Fe}$ treatments (Fig. 4Q-T) but exhibited no response to the light treatment (Table 3). This is because $\Phi_{\mathrm{m}}$ is directly proportional to $\alpha^{*}$ but inversely proportional to $\bar{a}^{*}$, and both $\alpha^{*}$ and $\bar{a}^{*}$ were affected by the DFe treatment but not the light treatment. DFe additions resulted in a greater increase in $\Phi_{\mathrm{m}}$ than in $\alpha^{*}$, since DFe additions also resulted in a decrease in $\bar{a}^{*} . \Phi_{\mathrm{m}}$ in the D treatments was in the range observed in HL and LL treatments, suggesting that the efficiency of photosynthesis remained unchanged when phytoplankton resided in the dark for $4 \mathrm{~d}$ (Fig. 4Q-T) or $6 \mathrm{~d}$ (results not shown). $\Phi_{\mathrm{m}}$ did not differ significantly among experiments (Table 3 ).

\subsection{Phytoplankton responses to DFe and light: pigments}

Phytoplankton altered their pigment composition in response to both the DFe and light treatments, although the specific response differed among experiments (Table 3). Chl $c_{3}$ is a photosynthetic pigment in P. antarctica and certain diatoms such as Pseudonitzschia spp. (Zapata et al. 2011). The chl $C_{3} / \mathrm{chl} a$ ratio ranged from 0.020 to 0.118 and was highest in Expts 1 and 3 where $P$. antarctica was most abundant (Table 4). Changes in chl $C_{3} / \mathrm{chl}$ a differed between experiments (Table 3), likely as a result of the different phytoplankton assemblage, but there was no effect of DFe or light treatments on the chl $c_{3} / \mathrm{chl}$ a ratio.

Fuco is an accessory pigment present in both diatoms and $P$. antarctica, but the Fuco/chl a ratios in diatoms are much higher than those in P. antarctica. Fuco/chl $a$ in the 4 experiments ranged from 0.38 to 0.81 (Table 4) and differed significantly among experiments (Table 3), likely as the result of differences in the phytoplankton assemblages. Neither DFe treatment nor light treatment had a significant effect on the $\mathrm{Fuco} / \mathrm{chl}$ a ratio.

$19^{\prime}$-Hex is the most abundant fucoxanthin in P. antarctica. The $19^{\prime}-\mathrm{Hex} / \mathrm{chl}$ a ratio ranged from 0.05 to 0.48 (Table 4) and was highest in Expts 1 and 3 that were dominated by $P$. antarctica. Likely as a result of this difference in $P$. antarctica contribution, $19^{\prime}-\mathrm{Hex} / \mathrm{chl}$ a differed significantly among experiments ( $p<0.05$; Table 3$) .19^{\prime}-\mathrm{Hex} / \mathrm{chl}$ a was affected by the DFe treatment (Table 3), being lower in the DFe-amended treatments than in the unamended controls (Table 4). The light treatment did not affect $19^{\prime}$-Hex/chl a ratio, nor was there an interaction between DFe and light.

$\beta$-Car is a photoprotective pigment in both $P$. antarctica and diatoms. The $\beta-\mathrm{Car} / \mathrm{chl}$ a ratio ranged from 0.013 to 0.047 (Table 4) and was similar among the 4 experiments. The $\beta$-Car/chl a ratio was higher in the $+\mathrm{Fe}$ treatments than in the controls and higher in HL than in the LL or D treatments. There were no significant interactive effects of the DFe and light treatment.

DD and DT are the main xanthophyll cycle pigments in both $P$. antarctica and diatoms. The (DD+ 
Table 4. Phytoplankton pigment ratios measured in the bioassay experiments after $4 \mathrm{~d}$. Data are means (SD) from triplicate bottles. Abbreviations as in Table 2

\begin{tabular}{|c|c|c|c|c|}
\hline Treatme & Expt 1 & Expt 2 & Expt 3 & Expt 4 \\
\hline \multicolumn{5}{|c|}{$\operatorname{chl} c_{3} / \operatorname{chl} a$} \\
\hline I & 0.059 & 0.065 & 0.108 & 0.022 \\
\hline $\mathrm{HL}-\mathrm{Fe}$ & $0.104(0.014)$ & $0.049(0.005)$ & $0.099(0.005)$ & $0.020(0.004)$ \\
\hline $\mathrm{HL}+\mathrm{Fe}$ & $0.057(0.004)$ & $0.035(0.000)$ & $0.070(0.003)$ & $0.022(0.002)$ \\
\hline LL-Fe & $0.088(0.006)$ & $0.033(0.008)$ & $0.105(0.003)$ & $0.022(0.014)$ \\
\hline $\mathrm{LL}+\mathrm{Fe}$ & $0.068(0.022)$ & $0.046(0.005)$ & $0.108(0.005)$ & $0.034(0.008)$ \\
\hline $\mathrm{D}-\mathrm{Fe}$ & nd & nd & $0.118(0.018)$ & $0.030(0.005)$ \\
\hline $\mathrm{D}+\mathrm{Fe}$ & nd & nd & $0.097(0.034)$ & $0.043(0.005)$ \\
\hline \multicolumn{5}{|c|}{ Fuco/chl a } \\
\hline I & 0.38 & 0.48 & 0.46 & 0.66 \\
\hline $\mathrm{HL}-\mathrm{Fe}$ & $0.38(0.01)$ & $0.51(0.02)$ & $0.43(0.01)$ & $0.79(0.14)$ \\
\hline $\mathrm{HL}+\mathrm{Fe}$ & $0.40(0.02)$ & $0.46(0.01)$ & $0.41(0.01)$ & $0.74(0.10)$ \\
\hline LL-Fe & $0.44(0.00)$ & $0.57(0.00)$ & $0.45(0.01)$ & $0.81(0.05)$ \\
\hline $\mathrm{LL}+\mathrm{Fe}$ & $0.45(0.01)$ & $0.56(0.01)$ & $0.47(0.02)$ & $0.70(0.03)$ \\
\hline $\mathrm{D}-\mathrm{Fe}$ & nd & nd & $0.47(0.00)$ & $0.68(0.03)$ \\
\hline $\mathrm{D}+\mathrm{Fe}$ & nd & nd & $0.47(0.02)$ & $0.64(0.01)$ \\
\hline \multicolumn{5}{|c|}{$19^{\prime} \mathrm{Hex} / \mathrm{chl} \mathrm{a}$} \\
\hline I & 0.48 & 0.28 & 0.36 & 0.09 \\
\hline $\mathrm{HL}-\mathrm{Fe}$ & $0.42(0.02)$ & $0.22(0.01)$ & $0.33(0.02)$ & $0.06(0.01)$ \\
\hline $\mathrm{HL}+\mathrm{Fe}$ & $0.15(0.04)$ & $0.14(0.00)$ & $0.21(0.01)$ & $0.05(0.02)$ \\
\hline LL-Fe & $0.41(0.02)$ & $0.22(0.02)$ & $0.43(0.01)$ & $0.08(0.02)$ \\
\hline $\mathrm{LL}+\mathrm{Fe}$ & $0.15(0.02)$ & $0.13(0.02)$ & $0.28(0.04)$ & $0.05(0.01)$ \\
\hline $\mathrm{D}-\mathrm{Fe}$ & nd & nd & $0.34(0.01)$ & $0.09(0.00)$ \\
\hline $\mathrm{D}+\mathrm{Fe}$ & nd & nd & $0.28(0.01)$ & $0.08(0.01)$ \\
\hline \multicolumn{5}{|c|}{$\beta-$ Car/chl a } \\
\hline I & 0.016 & 0.015 & 0.016 & 0.020 \\
\hline $\mathrm{HL}-\mathrm{Fe}$ & $0.028(0.002)$ & $0.031(0.000)$ & $0.031(0.000)$ & $0.035(0.005)$ \\
\hline $\mathrm{HL}+\mathrm{Fe}$ & $0.028(0.001)$ & $0.038(0.000)$ & $0.036(0.001)$ & $0.047(0.006)$ \\
\hline $\mathrm{LL}-\mathrm{Fe}$ & $0.016(0.002)$ & $0.015(0.001)$ & $0.016(0.000)$ & $0.019(0.002)$ \\
\hline $\mathrm{LL}+\mathrm{Fe}$ & $0.020(0.000)$ & $0.022(0.000)$ & $0.020(0.001)$ & $0.028(0.002)$ \\
\hline $\mathrm{D}-\mathrm{Fe}$ & nd & nd & $0.013(0.002)$ & $0.024(0.003)$ \\
\hline $\mathrm{D}+\mathrm{Fe}$ & nd & nd & $0.016(0.000)$ & $0.027(0.004)$ \\
\hline \multicolumn{5}{|c|}{$(\mathrm{DD}+\mathrm{DT}) / \mathrm{chl} a$} \\
\hline I & 0.12 & 0.14 & 0.09 & 0.22 \\
\hline $\mathrm{HL}-\mathrm{Fe}$ & $0.31(0.01)$ & $0.35(0.01)$ & $0.44(0.03)$ & $0.38(0.06)$ \\
\hline $\mathrm{HL}+\mathrm{Fe}$ & $0.22(0.02)$ & $0.33(0.01)$ & $0.38(0.01)$ & $0.42(0.06)$ \\
\hline LL-Fe & $0.10(0.01)$ & $0.11(0.01)$ & $0.13(0.01)$ & $0.15(0.03)$ \\
\hline $\mathrm{LL}+\mathrm{Fe}$ & $0.06(0.01)$ & $0.10(0.01)$ & $0.06(0.01)$ & $0.12(0.07)$ \\
\hline $\mathrm{D}-\mathrm{Fe}$ & nd & nd & $0.09(0.01)$ & $0.19(0.01)$ \\
\hline $\mathrm{D}+\mathrm{Fe}$ & nd & nd & $0.08(0.01)$ & $0.18(0.04)$ \\
\hline \multicolumn{5}{|l|}{ PPp/PSp } \\
\hline I & 0.07 & 0.08 & 0.05 & 0.13 \\
\hline $\mathrm{HL}-\mathrm{Fe}$ & $0.16(0.01)$ & $0.20(0.00)$ & $0.23(0.01)$ & $0.20(0.01)$ \\
\hline $\mathrm{HL}+\mathrm{Fe}$ & $0.14(0.01)$ & $0.21(0.00)$ & $0.23(0.01)$ & $0.24(0.02)$ \\
\hline $\mathrm{LL}-\mathrm{Fe}$ & $0.06(0.00)$ & $0.06(0.01)$ & $0.06(0.00)$ & $0.08(0.01)$ \\
\hline $\mathrm{LL}+\mathrm{Fe}$ & $0.04(0.00)$ & $0.06(0.00)$ & $0.04(0.00)$ & $0.08(0.04)$ \\
\hline $\mathrm{D}-\mathrm{Fe}$ & nd & nd & $0.05(0.01)$ & $0.11(0.00)$ \\
\hline $\mathrm{D}+\mathrm{Fe}$ & nd & nd & $0.05(0.00)$ & $0.11(0.02)$ \\
\hline
\end{tabular}

The ratio of all photoprotective pigments $(\mathrm{PPp}=\beta-\mathrm{Car}+\mathrm{DD}+\mathrm{DT}$; pigments from the violaxanthin cycle are not included here due to concentrations below our detection limit in many samples) to all photosynthetic pigments $\left(\mathrm{PSp}=\operatorname{chl} a+\operatorname{chl} c_{3}+\right.$ Fuco $)$ varied from 0.04 to 0.24 (Table 4). While the DFe treatment did not affect the PPp/PSp ratio, light had a strong effect, and PPp/PSp was significantly higher in the HL than in the LL or D treatments, which were similar.

\section{DISCUSSION}

Although the phytoplankton assemblage differed among the 4 experiments, with $P$. antarctica dominating Expt $1(69 \%)$ and diatoms dominating Expt $4(94 \%)$, the treatment effects on growth rates and photosynthetic rates were remarkably similar across all experiments. The similarity in photosynthetic parameters between diatom- and $P$. antarctica-dominated phytoplankton assemblages has been observed previously in the RSP (van Hilst \& Smith 2002, Robinson et al. 2003, Smith \& Donaldson 2015). In addition, while phytoplankton taxonomic composition is responsible for a large fraction of the variability in $F_{\mathrm{v}} / F_{\mathrm{m}}$ and $\sigma_{\mathrm{PSII}}$ in much of the global ocean, taxonomic effects are generally swamped by DFe effects in high nutrient low chlorophyll waters (Suggett et al. 2009). Nevertheless, we did observe that the primary photophysiological differences among the experiments were in the absorption parameters $\sigma_{\text {PSII }}$ and $\bar{a}^{*}$ which were slightly higher in diatom-dominated experiments, as reported previously by Ryan-Keogh et al. (2017a), and in photosynthetic pigment composition (Table 3). For the latter, this is to be expected because the composition of the phytoplankton assemblage was determined using pigment ratios, with Fuco assumed to be largely indicative of diatoms and 19'-Hex being a marker pigment for $P$. antarctica (Mackey et al. 1996). In addition, chl $C_{3}$, which is often used as a
DT)/chl a ratio ranged from 0.06 to 0.44 (Table 4) and was similar among the experiments $(p>0.05)$. The DFe treatment did not affect the (DD+DT)/chl a ratio, but it was significantly higher in the HL light treatments than in the LL and D treatments. 
marker pigment for P. antarctica (van Leeuwe et al. 2014), was highest in experiments dominated by that species.

\subsection{Fe and light effects on phytoplankton growth, biomass, and photosynthesis}

Due to low surface concentrations $(<0.1 \mathrm{nM}$; Gerringa et al. 2015), DFe availability limited phytoplankton growth during our cruise in the southern RSP in early summer. Our observations of DFe limitation agree with similar experiments reported previously for the Ross Sea (Sedwick et al. 2000, Bertrand et al. 2007, Rose et al. 2009, Feng et al. 2010), and the photosynthetic parameters measured in our experiments were consistent with a meta-analysis of 417 $P-E$ curves measured in the Ross Sea from 1994 to 2012 (Smith \& Donaldson 2015). Because of these low surface DFe concentrations, phytoplankton responded to DFe addition by increasing their growth rate, as well as the $P-E$ parameters $P_{\max }^{*}$ and $\alpha^{*}$ in all experiments in both HL and LL treatments. Our results are in good agreement with culture experiments on P. antarctica (van Leeuwe \& Stefels 2007, Alderkamp et al. 2012, Strzepek et al. 2012, 2019) and Antarctic diatoms (Alderkamp et al. 2012, Strzepek et al. 2012, 2019), and bioassay experiments in the Amundsen Sea (Alderkamp et al. 2015), Ross Sea (Feng et al. 2010), and the Atlantic sector of the Southern Ocean (Ryan-Keogh et al. 2017b).

Like growth rate, $\alpha^{*}$, and $P_{\text {max }}^{*} F_{\mathrm{v}} / F_{\mathrm{m}}$ also responded to both light and DFe in our experiments, being highest in LL treatments when DFe was added (Fig. 3). Similar observations were made for phytoplankton from the Western Antarctic Peninsula region of the Southern Ocean (Moreno et al. 2018), although in their study, $F_{\mathrm{v}} / F_{\mathrm{m}}$ was generally less responsive to DFe stress than was phytoplankton growth rate. Because Fe is an essential component of both the photosynthetic reaction centers and the electron transport chain, $\mathrm{Fe}$ stress is thought to reduce $F_{\mathrm{v}} / F_{\mathrm{m}}$ due to decoupling of chlorophyllbinding proteins from the light-harvesting complex (Behrenfeld et al. 2006, Macey et al. 2014, RyanKeogh et al. 2017a), reducing the efficiency of electron flow through PS II (Schrader et al. 2011). $F_{\mathrm{v}} / F_{\mathrm{m}}$ can also decline under high light stress due to photodamage of the reaction center (Kolber et al. 1988, 1994), indicating that the light levels phytoplankton experienced in our HL treatments (300-500 $\mu \mathrm{mol}$ photons $\mathrm{m}^{-2} \mathrm{~s}^{-1}$ ) may have been inducing a light stress response.
In many phytoplankton, increases in $F_{\mathrm{v}} / F_{\mathrm{m}}$ in response to DFe addition are associated with a decrease in $\sigma_{\text {PSII }}$ (Suggett et al. 2009, Strzepek et al. 2012, Ryan-Keogh et al. 2017a, Moreno et al. 2018). This is usually explained by the fact that excitons will have a longer lifetime within a larger antenna (higher $\sigma_{\mathrm{PSII}}$ ), increasing the probability of thermal dissipation and thereby reducing fluorescence (Lavergne \& Joliot 2000). However, we observed no such change in $\sigma_{\mathrm{PSII}}$ in response to either our light or DFe treatments (Table 3), which are well within the range of values summarized for diatoms and haptophytes by Suggett et al. (2009). The only significant effect on $\sigma_{\text {PSII }}$ was between experiments, with Expt 4 (dominated by diatoms) having significantly higher $\sigma_{\text {PSII }}$ than Expt 1 (dominated by $P$. antarctica), as observed previously by Ryan-Keogh et al. (2017a). This is in contrast to $\bar{a}^{*}$ (another measure of phytoplankton absorption), which also was higher in Expt 4 than Expt 1, but was significantly reduced in the + Fe treatments. This decrease in $\bar{a}^{*}$ with added DFe could be interpreted as an increase in cellular pigment concentration, resulting in greater pigment packaging (Morel \& Bricaud 1981). It appears that despite a decrease in light absorption per unit chl $a$ $\left(\bar{a}^{*}\right)$ at high $\mathrm{DFe}$, there was no associated decrease in the effective absorption cross section ( $\left.\sigma_{\mathrm{PSII}}\right)$.

$P_{\max }^{*}$ was the only growth or photosynthetic parameter in which there was an interaction between light and DFe (Table 3), increasing in response to both higher light and higher DFe. The higher light sensitivity of $P_{\max }^{*}$ in the presence of added DFe suggests that reaction centers that had become decoupled when DFe was lacking had been repaired, or new ones had been produced, increasing the flow of electrons through PS II and PS I to NADPH and resulting in higher rates of $\mathrm{CO}_{2}$ fixation. Repair of these reaction centers is also consistent with the large increase in $\Phi_{\mathrm{m}}$ and $F_{\mathrm{v}} / F_{\mathrm{m}}$ we measured at higher DFe treatments (Fig. 4). The lack of a similar interaction between light and DFe in $\alpha^{*}$ is probably because $\bar{a}^{*}$, which together with $\Phi_{\mathrm{m}}$ controls the magnitude of $\alpha^{*}$, declined at higher DFe concentrations due to pigment packaging, ameliorating the response of $\alpha^{*}$ to light. Increased pigment packaging due to increased chl a synthesis at high DFe is also consistent with the large drop in the POC/chl a ratio and the relatively constant $\mathrm{POC} / \mathrm{PON}$ ratio in the LL treatments when DFe was added ( $p<0.05$; Table 2). The consequence of greater pigment packaging at high DFe is that $\alpha^{*}$ in our experiments did not respond to changes in light to the same degree as $\operatorname{did} P_{\text {max }}^{*}$. 
The POC/PON ratio (mol:mol) exhibited relatively little variability across experiments (6.0-7.8; Table 2$)$ but was more sensitive to DFe additions than to light level (Table 3), decreasing significantly when DFe was added. Whether this was due to a decrease in carbon assimilation (unlikely given the increase in $P_{\max }^{*}$ in the $+\mathrm{Fe}$ treatments) or an increase in nitrogen assimilation is not known. However because the enzyme responsible for $\mathrm{NO}_{3}{ }^{-}$assimilation, nitrate reductase, requires Fe (Salisbury \& Ross 1978, Timmermans et al. 1994), it is reasonable to assume that increased DFe allowed for greater nitrogen assimilation and hence the reductions in POC/PON we observed at high DFe.

\subsection{Photoacclimation strategy}

For phytoplankton over much of the global ocean, an antagonistic relationship exists between photosynthetic light absorption and cellular Fe requirements, with Fe demand increasing when light is in short supply (Sunda \& Huntsman 1997). To maintain balanced growth at low light, phytoplankton must increase light absorption by expanding their photosynthetic apparatus, including the Fe-rich reaction centers and electron transport chain (Raven 1990). When growing in waters that are Fe-replete, phytoplankton can photoacclimate to low light by simply increasing their number of photosynthetic reaction centers (MacIntyre et al. 2002). However, in waters of the Southern Ocean, this strategy is of little use because surface DFe concentrations are too low (Sedwick et al. 2000, 2011). Instead, it has been suggested that phytoplankton photoacclimate to low light in DFe-deficient waters by increasing their antenna size instead of increasing numbers of Fe-rich reaction centers (Strzepek et al. 2012), allowing them to absorb more light without increasing their requirement for Fe.

Using measurements of Fe-limited and Fe-replete growth together with active fluorescence techniques, this photoacclimation strategy has been documented using phytoplankton cultures from throughout the Southern Ocean (Strzepek et al. 2012, Luxem et al. 2017, Meyerink et al. 2017, Moreno et al. 2018) and from mixed assemblages sampled in the Ross Sea (Ryan-Keogh et al. 2017a) and Weddell Sea (Hoppe et al. 2013). Strzepek et al. (2012) was the first to show that the ratio of Fe-limited to Fe-replete growth $\left(\mu_{-\mathrm{Fe}} / \mu_{+\mathrm{Fe}}\right)$ in Southern Ocean phytoplankton cultures did not decrease at low light, as would be expected if their photoacclimation strategy increased their Fe demand. Instead, $\mu_{-\mathrm{Fe}} / \mu_{+\mathrm{Fe}}$ increased at light intensities below $30 \mu \mathrm{mol}$ photons $\mathrm{m}^{-2} \mathrm{~s}^{-1}$, with the largest increase observed in cultures of $P$. antarctica, indicating that enhanced light absorption was achieved by increasing antenna size. Ryan-Keogh et al. (2017a) further showed that as the season progresses, phytoplankton in the Ross Sea that utilize the Fe-saving strategy of increasing their antenna size were favored over those that did not. They proposed that this strategy may help explain the seasonal transition from early $P$. antarctica-dominated to later diatomdominated blooms. This is consistent with our observation that diatoms have a larger effective absorption cross section than $P$. antarctica.

Our experiments also showed no change in $\mu_{-\mathrm{Fe}} /$ $\mu_{+\mathrm{Fe}}$ at light levels between 30 and $500 \mu \mathrm{mol}$ photons $\mathrm{m}^{-2} \mathrm{~s}^{-1}\left(\mu_{-\mathrm{Fe}} / \mu_{+\mathrm{Fe}}=0.62-0.70\right)$, consistent with the interpretation of Strzepek et al. (2012). However, we saw no increase in $\mu_{-\mathrm{Fe}} / \mu_{+\mathrm{Fe} e}$ at low light, presumably because our experiments had no treatments with light levels below $30 \mu$ mol photons $\mathrm{m}^{-2} \mathrm{~s}^{-1}$, the threshold below which Strzepek et al. (2012) saw their largest increases in $\mu_{-\mathrm{Fe}} / \mu_{+\mathrm{Fe}}$.

Another consequence of the photoacclimation strategy of increasing photosynthetic unit size, rather than number, is that chl a-normalized $P_{\max }^{*}$ should decrease in low light while $\alpha^{*}$ remains constant (MacIntyre et al. 2002). The theory behind this is as follows. At low light, the cellular pigment content and number and/or efficiency of photosystems are typically increased to maximize photon capture, which increases the initial slope of the $P-E$ curve when normalized to cellular carbon $\left(\alpha^{\mathrm{C}}\right)$, but results in no net change in photosynthetic efficiency when normalized to chl $a$. This is because chl a-normalized photosynthetic efficiency $\left(\alpha^{*}\right)$ is a product of the rate of photon absorption per unit $\operatorname{chl} a\left(a^{*}{ }_{p h}\right)$ and the amount of carbon fixed per photon absorbed $\left(\Phi_{\mathrm{m}}\right)$. At low light, increases in $\Phi_{\mathrm{m}}$ are offset by increases in pigment packaging at higher cellular pigment concentrations, which reduces $a^{*}$ ph and results in little or no change in $\alpha^{*}$. If phytoplankton acclimate to low light by increasing their antenna size, then the photosynthetic rate normalized to $\mathrm{chl} a$ when light is saturating ( $P_{\max }^{*}$ assuming no photoinhibition) will decrease while the maximum photosynthetic rate when normalized to carbon $\left(P_{\max }^{\mathrm{C}}\right)$ will be unchanged. Alternatively, if phytoplankton acclimate to low light by reducing the number of reaction centers, then $P_{\max }^{*}$ will remain unchanged while $P_{\max }^{\mathrm{C}}$ will decrease (MacIntyre et al. 2002).

To our knowledge, ours is the first set of experiments to use direct measurements of carbon fixation 
to show that natural phytoplankton assemblages in low iron waters photoacclimate by increasing antenna size. Indeed, our results show that at low light, $P_{\max }^{*}$ was significantly reduced and $\alpha^{*}$ was unchanged compared to the HL treatment, regardless of phytoplankton species composition. Furthermore, despite the fact that both $P_{\max }^{*}$ and $\alpha^{*}$ were higher in the $+\mathrm{Fe}$ treatment than in the unamended controls (Fig. 4), the change in these parameters as a function of light was the same as in the -Fe treatment. This corroborates our conclusion based on $\mu_{-\mathrm{Fe}} / \mu_{+\mathrm{Fe}}$ and suggests that Southern Ocean phytoplankton have evolved an Fe-saving strategy whereby they photoacclimate to low light by increasing their photosynthetic unit size, rather than photosynthetic unit number, even when DFe is made available. It appears this Fe-saving strategy is characteristic of both P. antarctica (that dominated Expt 1) and diatoms (that dominated Expt 4), suggesting a common adaptation among phytoplankton taxa that grow under Fe limitation in the Southern Ocean (Strzepek et al. 2012, 2019, Ryan-Keogh et al. 2017a).

\subsection{Fe and light effects on photoprotection and photoinhibition}

Southern Ocean phytoplankton live in an environment where light levels can change dramatically over timescales ranging from seconds to seasons. Because surface light levels over these high latitude waters are generally low compared to other ocean environments, phytoplankton have adapted by increasing their antenna size to maximize light absorption. Consequently, phytoplankton growing in polar waters have some of the highest per cell concentrations of chl a and a high degree of pigment packaging (Mitchell \& Holm-Hansen 1991). However, this enhanced capacity for light absorption makes them vulnerable to photodamage when light levels rapidly increase (Alderkamp et al. 2010, Cheah et al. 2017), such as when they are mixed vertically to the surface on cloud-free days or when sea ice cover suddenly disappears, exposing the surface ocean to light levels an order of magnitude higher than those at depth or beneath the ice (Perovich \& Polashenski 2012). Phytoplankton have a number of strategies for dealing with transient (hours) increases in potentially damaging light levels, including heat dissipation via the xanthophyll pigment cycle, alteration of PS II to PS I ratios, adjustment of RUBISCO activity, and photorepair of the D1 reaction center protein (MacIntyre et al. 2000, Lavaud et al. 2004, Pfannschmidt 2005,
Kropuenske et al. 2010). Antarctic phytoplankton exhibit various degrees of these strategies, with diatoms favoring photoprotection using xanthophyll cycle pigments and $P$. antarctica favoring photorepair (Kropuenske et al. 2010).

Under Fe stress, excessive light is thought to be especially damaging to photosystems due to the inability to process the large amount of energy within a limited number of reaction centers (van de Poll et al. 2005). Therefore, it is noteworthy that we observed no discernable photoinhibition in our $P-E$ experiments at light levels as high as $550 \mu \mathrm{mol}$ photons $\mathrm{m}^{-2} \mathrm{~s}^{-1}$. At least 2 strategies were employed by phytoplankton in our experiments to reduce the amount of photodamage incurred in the HL treatments. First, they increased their cellular concentrations of photoprotective carotenoids such as $\beta$-carotene (Table 4 ) to reduce the amount of light reaching the photosynthetic pigments and the highly vulnerable reaction centers. Second, phytoplankton enhanced their ability to harmlessly dissipate as heat the excess absorbed energy that may have reached the reaction centers by increasing their (DD+DT)/ chl a ratios (Olaizola \& Yamamoto 1994, Lavaud et al. 2002, van de Poll et al. 2005, van Leeuwe \& Stefels 2007). Both of these strategies were employed in our experiments in response to HL regardless of phytoplankton taxonomic composition and under both $+\mathrm{Fe}$ and -Fe conditions, although the production of $\beta$-carotene was significantly higher when more DFe was available. These results indicate that light levels control the cellular concentrations of photoprotective pigments, whereas the capacity for upregulation of these pigments is partly dependent on ambient DFe concentrations (van de Poll et al. 2005, Alderkamp et al. 2013).

\subsection{Dark incubations}

Because of the highly dynamic nature of their fluid environment, phytoplankton have evolved strategies to withstand periods of darkness ranging from days to months (Berges \& Falkowski 1998, Manoharan et al. 1999, Luder et al. 2002). In the Southern Ocean, phytoplankton are often mixed deeply within the water column (Mitchell et al. 1991, Mitchell \& HolmHansen 1991), resulting in extended periods (days) of near-darkness. Therefore, it is of interest to understand how Southern Ocean phytoplankton are able to cope with these conditions and quickly adjust when the light environment becomes more conducive to growth. 
Prior investigations of dark survival mechanisms suggest that photosynthetic organisms survive prolonged darkness (months) by preferential degradation of the photosynthetic apparatus together with resting cell formation, organic carbon uptake, utilization of stored carbohydrates and lipids, and reduced metabolic rates (Peters \& Thomas 1996, Manoharan et al. 1999, Baldisserotto et al. 2005, Montechiaro et al. 2006, Ferroni et al. 2007, Popels et al. 2007, Wulff et al. 2008, Reeves et al. 2011, McMinn \& Martin 2013). Although we did not expect to see these types of changes in phytoplankton physiology over the $4 \mathrm{~d}$ of darkness in our experiments, we were somewhat surprised by the similarity in phytoplankton responses between our LL and D treatments.

Although phytoplankton biomass and growth rate declined in the dark in our experiments, POC/PON ratios were virtually unchanged between the $\mathrm{D}$ and LL treatments (Table 2) and the $\mathrm{POC} / \mathrm{chl}$ a ratio changed very little. Furthermore, pigment composition and measures of photosynthetic light absorption $\left(\sigma_{\text {PSII }}\right.$ and $\left.\bar{a}^{*}\right)$ did not differ between LL and D treatments, indicating that little or no chl a degradation had taken place during the $4 \mathrm{~d}$ of darkness. More importantly, photosynthetic parameters such as $F_{\mathrm{v}} / F_{\mathrm{m}}$, $P_{\max }^{*}, \alpha^{*}$, and $\Phi_{\mathrm{m}}$ were unchanged in our experiments between the LL and D treatments. These results are consistent with previous observations showing that polar microalgae photoacclimate to prolonged darkness over a period of up to $60 \mathrm{~d}$, exhibiting large changes in $F_{\mathrm{v}} / F_{\mathrm{m}}$ and rates of electron transport (Reeves et al. 2011). Our study also agrees with others conducted all over the world showing that phytoplankton can successfully recover from exposure to complete darkness if that exposure lasts for a timescale of days to weeks (Murphy \& Cowles 1997, Popels et al. 2007, McMinn \& Martin 2013, Fang \& Sommer 2017, Schaub et al. 2017, Walter et al. 2017). Thus, when Southern Ocean phytoplankton growing within a deep mixed layer are carried down below the euphotic zone for a few days, they remain competent to start photosynthesizing once they are mixed up to the surface again.

\section{CONCLUSIONS}

Although the composition of the phytoplankton assemblage differed between the 4 experiments, the treatment effects on growth and photosynthetic rates were remarkably consistent, suggesting that similar adaptations to light and DFe have evolved among distantly related phytoplankton taxa. Due to low am- bient surface DFe concentrations, phytoplankton responded to DFe addition by increasing their growth rate, as well as $P_{\text {max }}^{*} \alpha^{*}$, and $F_{\mathrm{v}} / F_{\mathrm{m}} . P_{\text {max }}^{*}$ was the only growth or photosynthetic parameter in which there was an interaction between light and DFe, increasing in response to both higher light and higher DFe. This response suggests that previously non-functional reaction centers had been repaired upon addition of $\mathrm{DFe}$, increasing rates of both electron transport and $\mathrm{CO}_{2}$ fixation.

Our results also show that when Southern Ocean phytoplankton growing within a deep mixed layer are carried down below the euphotic zone for a few days, they remain competent to start photosynthesizing once they are mixed up to the surface again. Once in surface waters, phytoplankton employ additional strategies to reduce photodamage at high light, including increasing their cellular concentrations of photoprotective carotenoids and harmlessly dissipating excess absorbed energy as heat via the xanthophyll cycle.

For phytoplankton over much of the global ocean, Fe demand increases when light is in short supply (Sunda \& Huntsman 1997). However, our results confirm that in waters of the Southern Ocean where surface DFe concentrations are very low, phytoplankton have evolved an Fe-saving strategy whereby they photoacclimate to low light by increasing their antenna size instead of increasing numbers of Fe-rich reaction centers (Strzepek et al. 2012), even when DFe is made available. This ensures their competitive success in waters that are chronically depleted in some essential micronutrients.

Acknowledgements. We thank the captain and crew of the RVIB 'Nathaniel B. Palmer'. We are also grateful to the student volunteers who helped conduct this research. This research was funded by a grant from the National Science Foundation Office of Polar Programs to K.R.A. (ANT1063592).

\section{LITERATURE CITED}

Alderkamp AC, de Baar HJW, Visser RJW, Arrigo KR (2010) Can photoinhibition control phytoplankton abundance in deeply mixed water columns of the Southern Ocean? Limnol Oceanogr 55:1248-1264

Alderkamp AC, Garcon V, de Baar HJW, Arrigo KR (2011) Short-term photoacclimation effects on photoinhibition of phytoplankton in the Drake Passage (Southern Ocean). Deep Sea Res I 58:943-955

Alderkamp AC, Kulk G, Buma A, van Dijken G, Mills M, Visser R, Arrigo KR (2012) The effect of iron limitation on the photophysiology of Phaeocystis antarctica and Fragilariopsis cylindrus under dynamic irradiance. J Phycol $48: 45-59$ 
Alderkamp AC, Mills MM, van Dijken GL, Arrigo KR (2013) Photoacclimation and non-photochemical quenching under in situ irradiance in natural phytoplankotn assemblages from the Amundsen Sea, Antarctica. Mar Ecol Prog Ser 475:15-34

Alderkamp, AC, van Dijken GL, Lowry KE, Connelly TL and others (2015) Fe availability drives phytoplankton photosynthesis rates during spring bloom in the Amundsen Sea Polynya, Antarctica. Elem Sci Anth 3:p.000043

Arrigo KR, van Dijken GL (2003) Phytoplankton dynamics within 37 Antarctic coastal polynyas. J Geophys Res Oceans 108:3271

Arrigo KR, Robinson DH, Worthen DL, Dunbar RB, DiTullio GR, VanWoert M, Lizotte MP (1999) Phytoplankton community structure and the drawdown of nutrients and $\mathrm{CO}_{2}$ in the Southern Ocean. Science 283:365-367

* Arrigo KR, van Dijken GL, Long MC (2008) The coastal Southern Ocean: a strong anthropogenic $\mathrm{CO}_{2}$ sink. Geophys Res Lett 35:L21602

Arrigo KR, Mills MM, Kropuenske LR, van Dijken GL, Alderkamp AC, Robinson DH (2010) Photophysiology in two major Southern Ocean phytoplankton taxa: Photosynthesis and growth of Phaeocystis antarctica and Fragilariopsis cylindrus under different irradiance levels. Integr Comp Biol 50:950-966

Arrigo KR, van Dijken GL, Strong AL (2015) Environmental controls of marine productivity hot spots around Antarctica. J Geophys Res 120:5545-5565

Baldisserotto C, Ferroni L, Andreoli C, Fasulo MP, Bonora A, Pancaldi S (2005) Dark-acclimation of the chloroplast in Koliella antarctica exposed to a simulated austral night condition. Arct Antarct Alp Res 37:146-156

Barlow R, Lamont T, Kyewalyanga M, Sessions H, Morris T (2010) Phytoplankton production and physiological adaptation on the southeastern shelf of the Agulhas ecosystem. Cont Shelf Res 30:1472-1486

Behrenfeld MJ, Worthington K, Sherrell RM, Chavez FP, Strutton P, McPhaden M, Shea DM (2006) Controls on tropical Pacific Ocean productivity revealed through nutrient stress diagnostics. Nature 442: 1025-1028

* Berges JA, Falkowski PG (1998) Physiological stress and cell death in marine phytoplankton: induction of proteases in response to nitrogen or light limitation. Limnol Oceanogr 43:129-135

Bertrand EM, Rose JM, Riesselman CR, Lohan MC, Noble AE, Lee PA, DiTullio GR (2007) Vitamin $B_{12}$ and iron colimitation of phytoplankton growth in the Ross Sea. Limnol Oceanogr 52:1079-1093

* Boyd PW, Jickells T, Law CS, Blain S and others (2007) Mesoscale iron enrichment experiments 1993-2005: Synthesis and future directions. Science 315:612-617

Boyd PW, Arrigo KR, Strzepek R, van Dijken GL (2012) Mapping phytoplankton iron utilization: insights into Southern Ocean supply mechanisms. J Geophys Res 117: C06009

Bricaud A, Stramski D (1990) Spectral absorption-coefficients of living phytoplankton and nonalgal biogenous matter: a comparison between the Peru upwelling area and the Sargasso Sea. Limnol Oceanogr 35:562-582

* Cheah W, Soppa MA, Wiegmann S, Ossebaar S and others (2017) Importance of deep mixing and silicic acid in regulating phytoplankton biomass and community in the iron-limited Antarctic Polar Front region in summer. Deep Sea Res II 138:74-85
DiTullio GR, Grebmeier J, Arrigo KR, Lizotte MP and others (2000) Rapid and early export of Phaeocystis antarctica blooms in the Ross Sea, Antarctica. Nature 404:595-598

Falkowski PG, La Roche J (1991) Acclimation to spectral irradiance in algae. J Phycol 27:8-14

Fang X, Sommer U (2017) Overwintering effects on the spring bloom dynamics of phytoplankton. J Plankton Res 39:772-780

* Feng Y, Hare CE, Rose JM, Handy SM and others (2010) Interactive effects of iron, irradiance and $\mathrm{CO}_{2}$ on Ross Sea phytoplankton. Deep Sea Res I 57:368-383

*Ferroni L, Baldisserotto C, Zennaro V, Soldani C, Fasulo M, Pancaldi S (2007) Acclimation to darkness in the marine chlorophyte Koliella antarctica cultured under low salinity: hypotheses on its origin in the polar environment. Eur J Phycol 42:91-104

*Gerringa LJA, Laan P, van Dijken GL, van Haren H, De Baar HJW, Arrigo KR, Alderkamp AC (2015) Sources of iron in the Ross Sea polynya in late spring and summer. Mar Chem 177:447-459

*Gorbunov MY, Kolber ZS, Falkowski PG (1999) Measuring photosynthetic parameters in individual algal cells by Fast Repetition Rate fluorometry. Photosynth Res 62: 141-153

Grasshoff K, Ehrhardt M, Kremling K (1983) Methods of seawater analysis. Verlag Chemie, Wienheim

* Greene RM, Geider RJ, Kolber ZS, Falkowski PG (1992) Iron-induced changes in light harvesting and photochemical energy-conversion processes in eukaryotic marine-algae. Plant Physiol 100:565-575

Holm-Hansen O, Lorenzen C, Holmes RW, Strickland JDH (1965) Fluorometric determination of chlorophyll in Chlorophyta, Chrysophyta, Phaeophyta, Pyrrophyta. J Cons Perm Inter Explor Mer 30:3-15

* Hoppe CJM, Hassler CS, Payne CD, Tortell PD, Rost B, Trimborn S (2013) Iron Limitation Modulates Ocean Acidification Effects on Southern Ocean Phytoplankton Communities. PLOS ONE 8:e79890

*Hoppe CJM, Klaas C, Ossebaar S, Soppa MA and others (2017) Controls of primary production in two phytoplankton blooms in the Antarctic Circumpolar Current. Deep Sea Res II 138:63-73

Johnson Z, Barber RT (2003) The low-light reduction in the quantum yield of photosynthesis: potential errors and biases when calculating the maximum quantum yield. Photosynth Res 75:85-95

Kishino M, Takahashi M, Okami N, Ichimura S (1985) Estimation of the spectral absorption-coefficients of phytoplankton in the sea. Bull Mar Sci 37:634-642

Kolber Z, Zehr J, Falkowski PG (1988) Effects of growth irradiance and nitrogen limitation on photosynthetic energy conversion in Photosystem II. Plant Physiol 88:923-929

Kolber ZS, Barber RT, Coale KH, Fitzwater SE and others (1994) Iron limitation of phytoplankton photosynthesis in the equatorial Pacific Ocean. Nature 371:145-146

Kropuenske LR, Mills MM, van Dijken GL, Bailey S, Robinson DH, Welschmeyer NA, Arrigo KR (2009) Photophysiology in two major Southern Ocean phytoplankton taxa: photoprotection in Phaeocystis antarctica and Fragilariopsis cylindrus. Limnol Oceanogr 54:1176-1196

Kropuenske LR, Mills MM, van Dijken GL, Alderkamp AC and others (2010) Strategies and rates of photoacclimation in two major Southern Ocean phytoplankton taxa: Phaeocystis antarctica (Haptophyta) and Fragilariopsis cylindrus (Bacillariophyceae). J Phycol 46:1138-1151 
Lavaud J, Rousseau B, Van Gorkum HJ, Etienne A (2002) Influence of the diadinoxanthin pool size on photoprotection in the marine planktonic diatom Phaeodactylum tricornutum. Plant Physiol 129:1398-1406

Lavaud J, Rousseau B, Etienne AL (2004) General features of photoprotection by energy dissipation in planktonic diatoms (Bacillariophyceae). J Phycol 40:130-137

Lavergne J, Joliot P (2000) Thermodynamics of the excited states of photosynthesis. In: Cramer WA (ed) Biophysics textbook onLine. Biophysical Society, Bethesda, MD, p 1-12

Lewis MR, Smith JC (1983) A small volume, short-incubation-time method for measurement of photosynthesis as a function of incident irradiance. Mar Ecol Prog Ser 13: 99-102

Luder UH, Wiencke C, Knoetzel J (2002) Acclimation of photosynthesis and pigments during and after six months of darkness in Palmaria decipiens (Rhodophyta): a study to simulate Antarctic winter sea ice cover. J Phycol 38: 904-913

Luxem KE, Ellwood MJ, Strzepek RF (2017) Intraspecific variability in Phaeocystis antarctica's response to iron and light stress. PLOS ONE 12:e0179751

Macey AI, Ryan-Keogh T, Richier S, Moore CM, Bibby TS (2014) Photosynthetic protein stoichiometry and photophysiology in the high latitude North Atlantic. Limnol Oceanogr 59:1853-1864

* MacIntyre HL, Kana TM, Geider RJ (2000) The effect of water motion on short-term rates of photosynthesis by marine phytoplankton. Trends Plant Sci 5:12-17

MacIntyre HL, Kana TM, Anning T, Geider RJ (2002) Photoacclimation of photosynthesis irradiance response curves and photosynthetic pigments in microalgae and cyanobacteria. J Phycol 38:17-38

* Mackey MD, Mackey DJ, Higgins HW, Wright SW (1996) CHEMTAX - a program for estimating class abundances from chemical markers: application to HPLC measurements of phytoplankton. Mar Ecol Prog Ser 144:265-283

Maldonado MT, Boyd PW, Harrison PJ, Price NM (1999) Colimitation of phytoplankton growth by light and Fe during winter in the NE subarctic Pacific Ocean. Deep Sea Res II 46:2475-2485

Manoharan K, Lee TK, Cha JM, Kim JH and others (1999) Acclimation of Prorocentrum minimum (Dinophyceae) to prolonged darkness by use of an alternative carbon source from triacylglycerides and galactolipids. J Phycol 35:287-292

Martin JH, Fitzwater SE, Gordon RM (1990) Iron deficiency limits phytoplankton growth in Antarctic waters. Global Biogeochem Cycles 4:5-12

McDougall TJ, Feistel R, Millero FJ, Jackett DR and others (2009) Calculation of the thermodynamic properties of seawater, Global ship-based repeat hydrography manual. IOCCP Report 14. ICPO Publication Series 134. UNESCO, Paris

McMinn A, Martin A (2013) Dark survival in a warming world. Proc Biol Sci 280:20122909

Meyerink SW, Ellwood MJ, Maher WA, Proce GD, Strzepek RF (2017) Effects of iron limitation on silicon uptake kinetics and elemental stoichiometry in two Southern Ocean diatoms, Eucampia antarctica and Proboscia inermis, and the temperate diatom Thalassiosira pseudonana. Limnol Oceanogr 62:2445-2462

Mills MM, Kropuenske LR, van Dijken GL, Robinson DH and others (2010) Photophysiology in two major South- ern Ocean phytoplankton taxa: Photosynthesis and growth of Phaeocystis antarctica and Fragilariopsis cylindrus under simulated mixed-layer irradiance. J Phycol 46:1114-1127

*Mills MM, Alderkamp AC, Thurcózy CE, van Dijken GL, Laan P, de Baar H, Arrigo KR (2012) Phytoplankton biomass and pigment responses to Fe amendments in the Pine Island and Amundsen polynyas. Deep Sea Res II 71-76:61-76

Mitchell BG, Holm-Hansen O (1991) Bio-optical properties of Antarctic Peninsula waters: differentiation from temperate ocean models. Deep Sea Res A 38: 1009-1028

Mitchell BG, Kiefer DA (1988) Chlorophyll-alpha specific absorption and fluorescence excitation-spectra for lightlimited phytoplankton. Deep Sea Res I 35:639-663

*Mitchell BG, Brody EA, Holm-Hansen O, McClain C, Bishop J (1991) Light limitation of phytoplankton biomass and macronutrient utilization in the Southern Ocean. Limnol Oceanogr 36:1662-1677

*Montechiaro F, Hirschmugl CJ, Raven JA, Giordano M (2006) Homeostasis of cell composition during prolonged darkness. Plant Cell Environ 29:2198-2204

Montes-Hugo M, Doney SC, Ducklow HW, Fraser W, Martinson D, Stammerjohn S, Schofield O (2009) Recent changes in phytoplankton communities associated with rapid regional climate change along Western Antarctic Peninsula. Science 323:1470-1473

Morel A, Bricaud A (1981) Theoretical results concerning light absorption in a discrete medium and application to specific absorption of phytoplankton. Deep Sea Res A 28: 1375-1393

KMoreno CM, Lin Y, Davies S, Monbureau E, Cassar N, Marchetti A (2018) Examination of gene repertoires and physiological responses to iron and light limitation in Southern Ocean diatoms. Polar Biol 41:679-696

* Murphy AM, Cowles TJ (1997) Effects of darkness on multiexcitation in vivo fluorescence and survival in a marine diatom. Limnol Oceanogr 42:1444-1453

* Olaizola M, Yamamoto HY (1994) Short-term response of the diadinoxanthin cycle and fluorescence yield to high irradiance in Chaetoceros muelleri (Bacillariophyceae). J Phycol 30:606-612

Orsi AH, Wiederwohl CL (2009) A recount of Ross Sea waters. Deep Sea Res II 56:778-795

*Perovich DK, Polashenski C (2012) Albedo evolution of seasonal Arctic sea ice. Geophys Res Lett 39:L08501

* Peters E, Thomas DN (1996) Prolonged darkness and diatom mortality. I: Marine Antarctic species. J Exp Mar Biol Ecol 207:25-41

*Pfannschmidt T (2005) Acclimation to varying light qualities: towards the functional relationship of state transitions and adjustment of photosystem stoichiometry. J Phycol 41:723-725

Platt T, Gallegos CL, Harrison WG (1980) Photoinhibition of photosynthesis in natural assemblages of marine-phytoplankton. J Mar Res 38:687-701

* Popels L, MacIntyre HL, Warner ME, Zhang Y, Hutchins DA (2007) Physiological responses during dark survival and recovery in Aureococcus anophagefferens (Pelagophyceae). J Phycol 43:32-42

Raven JA (1990) Predictions of Mn and Fe use efficiencies of phototrophic growth as a function of light availability for growth and of $\mathrm{C}$ assimilation pathway. New Phytol 116: $1-18$ 
Reeves S, McMinn A, Martin A (2011) The effect of prolonged darkness on the growth, recovery and survival of Antarctic sea ice diatoms. Polar Biol 34:1019-1032

*Robinson DH, Arrigo KR, DiTullio GR, Lizotte MP (2003) Evaluating photosynthetic carbon fixation during Phaeocystis antarctica blooms. In DiTullio GR, Dunbar RB (eds) Biogeochemistry of the Ross Sea. Ant Res Ser 78:77-91

Rochaix JD (2011) Regulation of photosynthetic electron transport. Biochim Biophys Acta 1807:375-383

Rose JM, Feng Y, DiTullio GR, Dunbar RB and others (2009) Synergistic effects of iron and temperature on Antarctic phytoplankton and microzooplankton assemblages. Biogeosciences 6:3131-3147

Rose JM, Fitzpatrick E, Wang A, Gast RJ, Caron DA (2013) Low temperature constrains growth rates but not shortterm ingestion rates of Antarctic ciliates. Polar Biol 36: 645-659

Ryan-Keogh TJ, DeLizo LM, Smith WO Jr, Sedwick PN, McGillicuddy DJ Jr, Moore CM, Bibby TS (2017a) Temporal progression of photosynthetic strategy by phytoplankton in the Ross Sea, Antarctica. J Mar Syst 166:87-96

Kyan-Keogh TJ, Thomalla SJ, Mtshali TN, Little H (2017b) Modelled estimates of spatial variability of iron stress in the Atlantic sector of the Southern Ocean. Biogeosciences 14:3883-3897

Salisbury FB, Ross CW (1978) Plant physiology. Wadsworth Publishing Company, Belmont, CA

* Schaub I, Wagner H, Graeve M, Karsten U (2017) Effects of prolonged darkness and temperature on the lipid metabolism in the benthic diatom Navicula perminuta from the Arctic Adventfjorden, Svalbard. Polar Biol 40:1425-1439

Schrader PS, Milligan AJ, Behrenfeld MJ (2011) Surplus photosynthetic antennae complexes underlie diagnostics of iron limitation in a cyanobacterium. PLOS ONE 6:e18753

Sedwick P, DiTullio G, Mackey DJ (2000) Iron and manganese in the Ross Sea, Antarctica: Seasonal iron limitation in Antarctic shelf waters. J Geophys Res 105:11321-11336

Sedwick PN, Marsay CM, Aguilar-Islas AM, Lohan MC and others (2011) Early-season iron depletion in the Ross Sea polynya: Implications for iron dynamics on the Antarctic continental shelf. J Geophys Res 116:C12019

Selz V, Lowry KE, Lewis KM, Joy-Warren HL and others (2018) Distribution and photophysiology of spring sea ice algal communities and their potential to seed phytoplankton across the west Antarctic Peninsula. Mar Ecol Prog Ser 586:91-112

Smith WO Jr, Donaldson K (2015) Photosynthesis-irradiance responses in the Ross Sea, Antarctica: a meta-analysis. Biogeosciences 12:3567-3577

* Stammerjohn SE, Martinson DG, Smith RC, Iannuzzi RA (2008) Sea ice in the western Antarctic Peninsula region: Spatio-temporal variability from ecological and climate change perspectives. Deep Sea Res II 55:2041-2058

Strzepek RF, Hunter KA, Frew RD, Harrison PJ, Boyd PW (2012) Iron-light interactions differ in Southern Ocean phytoplankton. Limnol Oceanogr 57:1182-1200

Strzepek RF, Boyd PW, Sunda G (2019) Photosynthetic adaptation to low iron, light, and temperature in Southern Ocean phytoplankton. Proc Natl Acad Sci USA 116: 4388-4393

Suggett DJ, Moore CM, Hickman AE, Geider RJ (2009)

Editorial responsibility: Antonio Bode,

A Coruña, Spain
Interpretation of fast repetition rate (FRR) fluorescence: signatures of phytoplankton community structure versus physiological state. Mar Ecol Prog Ser 376:1-19

Sunda WG, Huntsman SA (1997) Interrelated influence of iron, light and cell size on marine phytoplankton growth. Nature 390:389-392

* Timmermans KR, Stolte W, de Baar HJW (1994) Iron-mediated effects on nitrate reductase in marine phytoplankton. Mar Biol 121:389-396

Tomczak M, Godfrey JS (2001) Regional oceanography: an introduction. Elsevier, Oxford

* Trimborn S, Brenneis T, Hoppe CJM, Laglera LM and others (2017) Iron sources alter the response of Southern Ocean phytoplankton to ocean acidification. Mar Ecol Prog Ser 578:35-50

van de Poll WH, van Leeuwe MA, Roggeveld J, Buma AGJ (2005) Nutrient limitation and high irradiance acclimation reduce PAR and UV-induced viability loss in the Antarctic diatom Chaetoceros brevis (Bacillariophyceae). J Phycol 41:840-850

* van de Poll WH, Lagunas M, de Vries T, Visser RJW, Buma AGJ (2011) Non-photochemical quenching of chlorophyll fluorescence and xanthophyll cycle responses after excess PAR and UVR in Chaetoceros brevis, Phaeocystis antarctica and coastal Antarctic phytoplankton. Mar Ecol Prog Ser 426:119-131

* Van Heukelem L, Thomas CS (2001) Computer-assisted high-performance liquid chromatography method development with applications to the isolation and analysis of phytoplankton pigments. J Chromatogr A 910:31-49

*van Hilst CM, Smith WO Jr (2002) Photosynthesis/irradiance relationships in the Ross Sea, Antarctica and their control by phytoplankton assemblage composition and environmental factors. Mar Ecol Prog Ser 226:1-12

*van Leeuwe MA, Stefels J (2007) Photosynthetic responses in Phaeocystis antarctica towards varying light and iron conditions. Biogeochemistry 83:61-70

*van Leeuwe MA, Villerius LA, Roggeveld J, Visser RJW, Stefels J (2006) An optimized method for automated analysis of algal pigments by HPLC. Mar Chem 102: 267-275

*van Leeuwe MA, Visser RJ, Stefels J (2014) The pigment composition of Phaeocystis antarctica (Haptophyceae) under various conditions of light, temperature, salinity, and iron. J Phycol 50:1070-1080

*Walter B, Peters J, van Beusekom JEE (2017) The effect of constant darkness and short light periods on the survival and physiological fitness of two phytoplankton species and their growth potential after re-illumination. Aquat Ecol 51:591-603

Webb WL, Newton M, Starr D (1974) Carbon-dioxide exchange of Alnus rubra-mathematical-model. Oecologia 17:281-291

*Wulff A, Roleda MY, Zacher K, Wiencke C (2008) Exposure to sudden light burst after prolonged darkness - a case study on benthic diatoms in Antarctica. Diatom Res 23: 519-532

Kapata M, Rodrıguez F, Fraga S, Barra L, Ruggiero MV (2011) Chlorophyll $c$ pigment patterns in 18 species (51 strains) of the genus Pseudo-nitzschia (Bacillariophyceae). J Phycol 47:1274-1280

Submitted: October 15, 2018; Accepted: May 22, 2019

Proofs received from author(s): July 1, 2019 